\title{
The Evolutionary Stages and Petrology of the Kekuknai Volcanic Massif Reflecting the Magmatism in the Backarc Zone of the Kuril-Kamchatka Island Arc System. Part II. Petrologic and Mineralogical Features, Petrogenesis Model
}

\author{
A. V. Koloskov ${ }^{a}$, G. B. Flerov ${ }^{a}$, A. B. Perepelov ${ }^{b}$, I. V. Melekestsev ${ }^{a}$, \\ M. Yu. Puzankov ${ }^{a}$, and T. M. Filosofova ${ }^{a}$ \\ ${ }^{a}$ Institute of Volcanology and Seismology, Far East Branch, Russian Academy of Sciences, \\ Piipa bul'var, 9, Petropavlovsk-Kamchatskii, 683006 Russia \\ e-mail:kolosav@ksnet.ru \\ ${ }^{b}$ Vinogradov Institute of Geochemistry, Siberian Branch, Russian Academy of Sciences, \\ ul. Favorskogo, 1A, Irkutsk, 664033 Russia \\ e-mail: region@igc.irk.ru \\ Received: March, 20, 2012
}

\begin{abstract}
The Kekuknai massif was formed in the course of tectono-magmatic activity that involved the origin of a shield volcano and a caldera depression with associated emplacement of extrusions that terminated in intense post-caldera areal volcanism. The mineralogical compositions of the massif's rocks have been considered in detail. The use of previously known and newly developed indicator properties of rock-forming minerals allowed the reconstruction of the general picture of the magmatic melt evolution and conditions of rock crystallization (various fluid and water saturation levels, as well as the oxidation state of the system). Essentially island-arc or intraplate characteristics of the massif's rock compositions are found at different stages of development of a single fluid-magmatic system. Decompression evolution of the parent deep-seated basanitic magma occurred via occurrence in intermediate magma chambers of daughter magmas of trachybasalt (pre-caldera stage) or hawaiite (areal volcanism) composition. Subsequent emanate-magmatic differentiation of these melts, combined with crystallization differentiation under changing $\mathrm{P}-\mathrm{T}-\mathrm{f}_{\mathrm{O}_{2}}$ conditions, resulted in the formation of the entire diversity of the Kekuknai rocks.
\end{abstract}

DOI: $10.1134 / \mathrm{S} 0742046313020048$

\section{INTRODUCTION}

The Kekuknai massif is a complex geological structure that formed in the course of the multistage evolution of a fluid-magmatic system from the end of the Late Pliocene and during the entire Quaternary period. The long-term volcanism and occurrence of contrast rock types in the massif provides a favorable situation for solving many problems of the relationships between volcanism and geodynamics.

In the first part of this paper [Koloskov et al, 2011] we presented a detailed description of the Kekuknai geological structure and data on the petrochemical, geochemical and isotopic composition of the massif rocks.

The Kekuknai massif was formed in the course of tectonic and magmatic activity that involved the generation of a shield-shaped volcano and a caldera depression with associated emplacement of extrusions followed by intense post-caldera areal volcanism. On the basis of geochemical data, island-arc and intraplate geochemical rock types were recognized in the massif; these types were reflections of a constructive and a subsequent destructive stage of the region's development. The formation of the massif took place under the conditions of an open system; therefore, the petrogenesis was dominated by the dynamics of the fluid phase, which was moderately affected by fractional crystallization and hybridism.

In this, the second part of our study, we will try to determine how those processes were reflected in the mineral composition of the rocks and to approach the development of a general petrologic model.

Conventional petrographic examination of rocks was supplemented by studies of mineral compositions using the CAMEBAX X-ray microanalyser at the Institute of Volcanology and Seismology at the Far East Branch of the Russian Academy of Sciences (the ordinary accuracy of the analysis is about $0.1 \%$ for major components and $10 \%$ for minor concentrations). Since the rocks are mostly aphyric and sub-aphyric varieties, 
studies were carried out, not in thin sections and polished sections only, but also in monomineral cartridges of artificial heavy concentrates with grains larger than $0.25 \mathrm{~mm}$.

\section{THE PETROGRAPHY AND MINERALOGY OF KEKUKNAI ROCKS}

\section{Distribution of Rocks of Different Types, Petrologic and Geochemical Associations}

In this paper the following rock associations are discussed (Fig. 1, Table 1).

I. A trachybasalt-trachydacite association, which reflects the rocks of the pre-caldera edifice of the shieldshaped volcano and extrusions of the caldera generation stage.

II. A trachybasalt association.

III. An andesite-basalt association (cinder cones of the earlier stage of areal volcanism).

IV. A hawaiite-andesite-basalt (mugearite) association of the middle stage of areal volcanism.

V. A trachybasalt-hawaiite-andesite-basalt (mugearite) association of the late stage of areal volcanism.

The rock compositions of these associations are displayed on several petrologic-geochemical diagrams as fields and figurative points (Fig. 2). The most individualized composition fields are those for associations I and IV (Fig. 2a). Association I rocks are characterized by lower $\mathrm{Nb}$ concentrations and form a separate field with the trend of a direct correlation $\mathrm{Nb}-\mathrm{K}$ relationship, which is a typical feature of island-arc (orogenic) volcanic rocks. Association IV rock compositions perfectly agree with so-called intraplate volcanic rocks with high contents of high-field strength elements and the absence of an $\mathrm{Nb}-\mathrm{K}$ correlation. The three other associations are intermediate between these two compositions. It is of interest to understand how these geochemical features are reflected in the corresponding petrographic and mineralogical characteristics of rocks and in the manner in which they originated.

\section{Textural and Petro-Chemical Characteristics of Rocks}

Generally, the rocks of the identified associations notably differ in textural appearance. The lavas of the shield-shaped edifice and extrusion rocks are of seriesporphyric and thick-fine-porphyric textures, while the areal volcanic rocks are of sub-aphyric and thin-fineporphyric textures. Depending on the facies in question (neck, cinder, bomb, or lava) and the degree of rock crystallinity, a wide diversity of ground mass microtextures is observed, from vitrophyric and hyalopilitic to pilotaxitic and microdoleritic. Considering the different degrees of rock crystallinity and the significant presence of sub-aphyric varieties, one of the discrimination criteria of volcanic rocks may be their normative composi- tion and the difference between modal and normative compositions may indicate the crystallization conditions (Table 1). Further presentation of the data largely involves a comparison of the normative and modal compositions of rocks, as well as the correlation of the compositions of the Kekuknai minerals with some type associations. The latter is the result of studies of olivines [Volynets et al., 1975] and plagioclases [Volynets and Koloskov, 1976] from different rock types (largely calcalkaline and tholeiitic) of Quaternary basalts in Kamchatka and the Kuril Islands). In addition, the authors have access to huge analytical data on the compositions of rocks of the Pliocene Belogolovskii volcano, whose high-alkalinity and wide range of silicic acidity classify it as belonging to the intraplate geochemical type [Volynets, 1994].

The presence of quartz in the normative composition (Table 1) is noted in all the rocks of high silicic acidity (beginning with andesite-basalts), but a few grains of quartz were found only in some samples of trachybasalts, mugearites, and hawaiites. Nepheline in normative compositions is absent from pre-caldera rocks but is typical of areal hawaiites and trachybasalts. No feldspathoids are found in modal compositions.

In the calculated compositions, hypersthene occurs in almost all the rock varieties with the exception of hawaiites and trachybasalts in the neck (sample k53). Modal orthopyroxene is found in the rocks of the shield-shaped volcano, trachyandesite of extrusions, in almost all varieties (except for trachybasalts and mugearites) of the early and middle stages, but is absent from all the rocks of the late stage of areal volcanism.

Normative olivine is a characteristic feature of areal type rocks. However, modal olivine is much more abundant, occurring as well in andesite-basalts of the areal type with no normative equivalent, although in different amounts.

Modal and normative plagioclase compositions differ sharply in all the rock varieties. This is the most acute problem in the justification of the nomenclature of hawaiites and mugearites (hawaiites are rocks with modal andesine and mugearites, with oligoclase).

Now we consider the petrographic compositions of the major rock varieties of the massif.

Trachybasalts-trachyandesites of the shield-shaped volcano edifice have a higher crystallinity: the fraction of phenocrysts and sub-phenocrysts reaches $75 \mathrm{vol} \%$. On the basis of phenocryst composition, the trachybasalts are feldspar-dominated orthopyroxene-olivineclinopyroxene-plagioclase varieties. These rocks are characterized by the presence of titanomagnetite (Fig. 3), which occurs in olivine and pyroxene phenocrysts. The groundmass includes microlites of the same minerals, potassium-sodium feldspar and alkaline glass in the mesostasis. As the silicic acidity of rocks increases, the olivine content in basalts decreases as far 

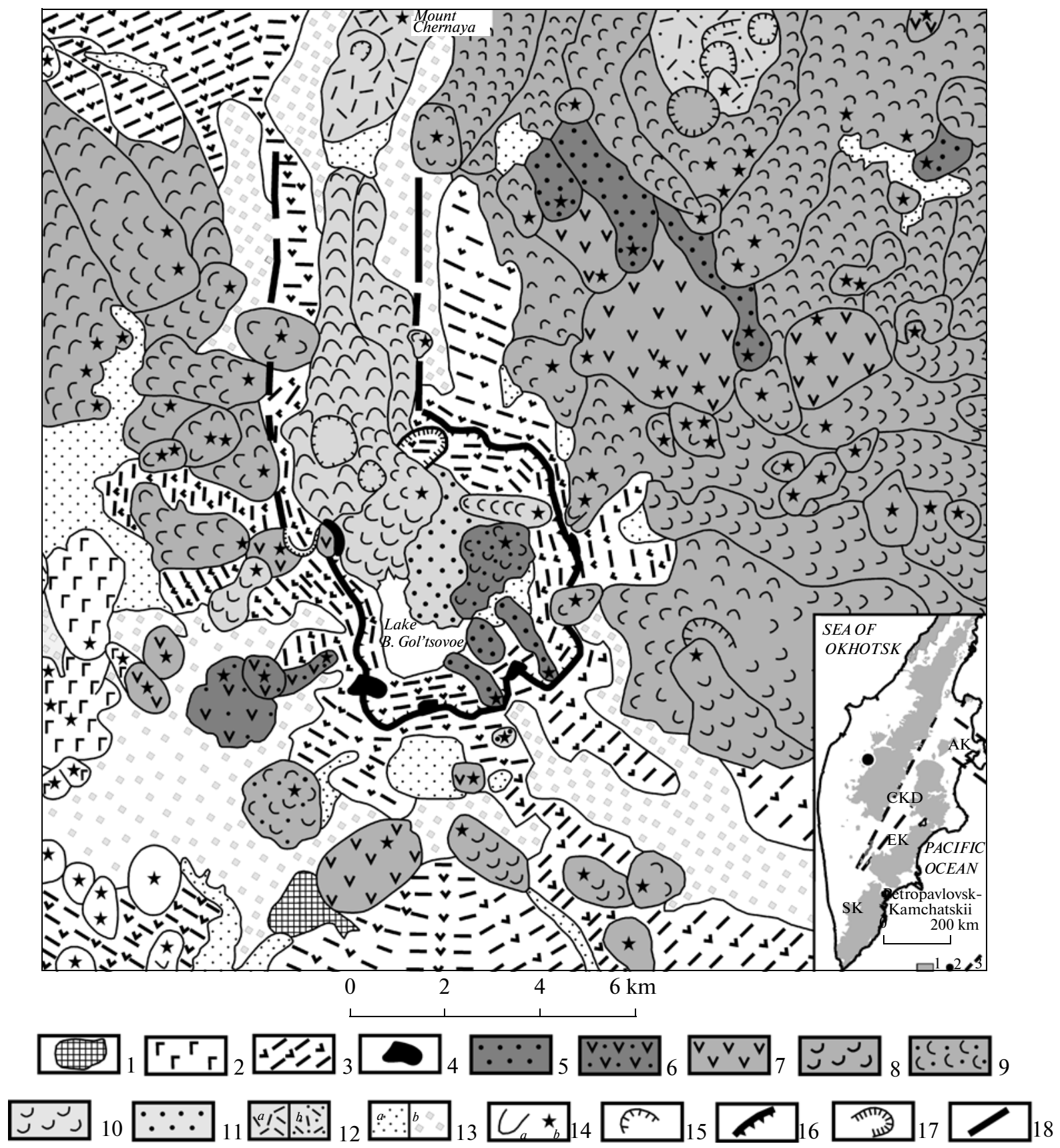

Fig. 1. The distribution of magmatic rocks of Kekuknai massif. (1) Miocene-Pliocene volcanogenic rocks of the basement $\left(\mathrm{N}_{1-2}\right)$; (2) hawaiites and andesites of the Mount Bol'shaya massif $\left(\mathrm{Q}_{3}\right)$. Kekuknai massif: (3) trachybasalt-trachyandesites of the shieldshaped volcano of the pre-caldera stage $\left(Q_{1-2}\right)$; (4) trachyandesites and trachydacites of the extrusions of syn-caldera stage $\left(Q_{1-2}\right)$ (association I). The post-caldera stage $\left(\mathrm{Q}_{3}^{2}-\mathrm{Q}_{4}\right)$. The early stage: (5) trachybasalts (association II); (6) amphibole andesite-basalts (association III). Middle stage: (7) basaltic andesite, (8) rocks of the hawaiite-mugearite series, (9) rocks of the hawaiite-trachybasalt-mugearite composition (association IV). The late stage: (10) rocks of hawaiite-mugearite series; (11) trachybasalts; (12) andesite-basalts, andesites (a) and trachyrhyolites (b) (association V); (13) accumulative deposits of various origins $\left(Q_{3}^{4}-Q_{4}\right)$ : fluvioglacial, alluvial, lacustrine, etc. $(a)$, moraines of phase II of the Late Pleistocene glaciation $(b)$; (14) lava flows $(a)$ and eruptive centers (b); (15) explosive craters, maars, funnels of phreatic explosions on lava flows; (16) escarp of the volcano-tectonic caldera; (17) faults, collapses; (18) inferred tectonic faults.

In the insert: location of Kekuknai volcanic massif within volcanic belts of Kamchatka island-arc system. (1) Cenozoic volcanic belts of Kamchatka (SR, Sredinny Range; SK, southern; and EK, eastern Kamchatka); (2) Kekuknai volcanic massif; (3) approximate boundaries of central Kamchatka depression (CKD) and the structure of Aleutian-Kamchatka junction (AK). 

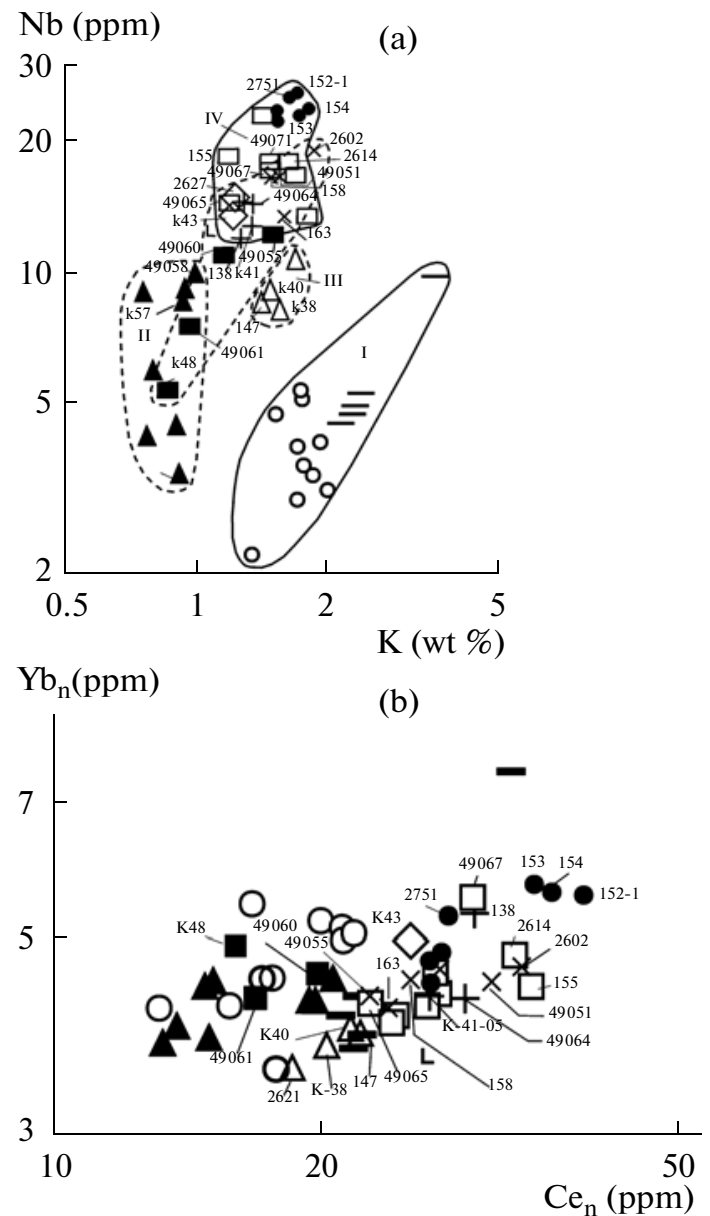

$\mathrm{TiO}_{2}(\mathrm{wt} \%)$

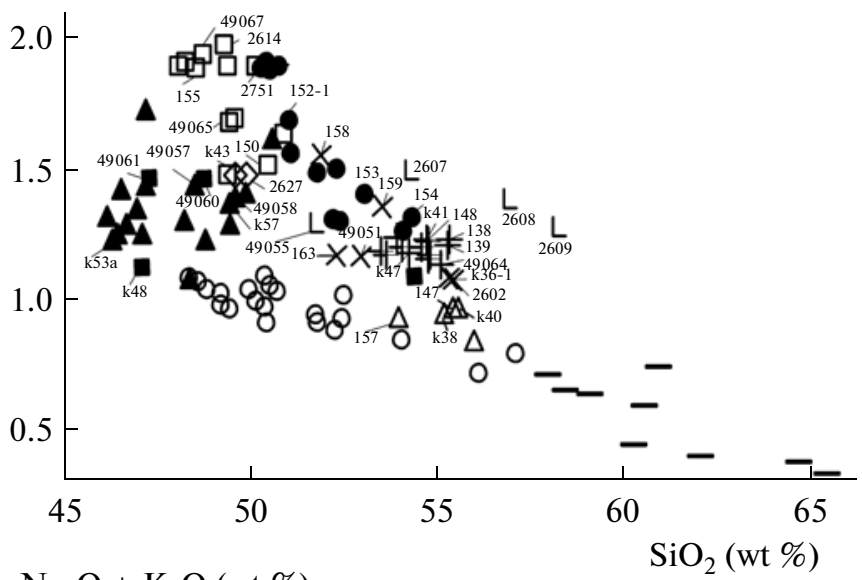

$\mathrm{Na}_{2} \mathrm{O}+\mathrm{K}_{2} \mathrm{O}($ wt \%)

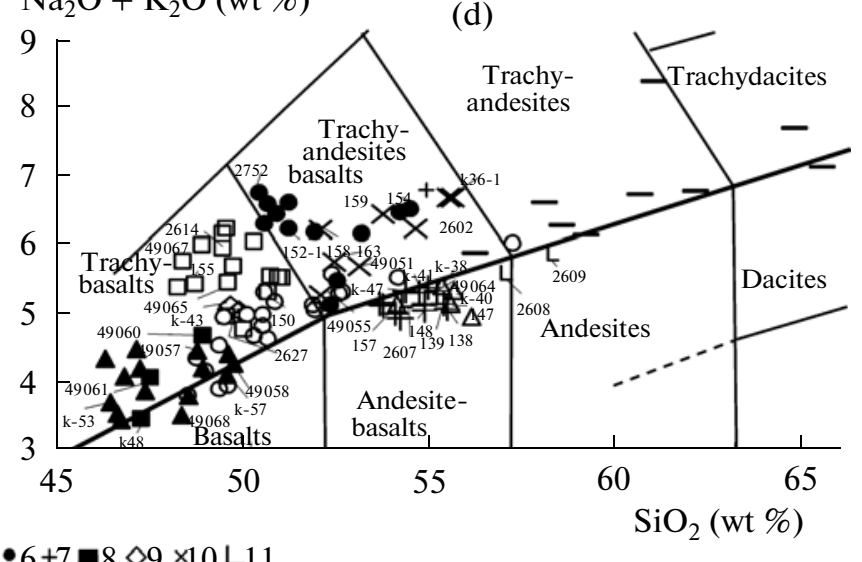

Fig. 2. Diagram of compositions of volcanic rocks of Kekuknai massif in the following coordinates: $\mathrm{Nb}-\mathrm{K}(\mathrm{a}), \mathrm{Yb}_{\mathrm{n}}-\mathrm{Ce}_{\mathrm{n}}(\mathrm{b}), \mathrm{TiO}_{2}-$ $\mathrm{SiO}_{2}$ (c) and $\mathrm{Na}_{2} \mathrm{O}+\mathrm{K}_{2} \mathrm{O}-\mathrm{SiO}_{2}$ (d). (1-2) Pre-caldera stage and extrusions: (1) trachybasalts-trachyandesites of the shieldshaped volcano edifice, (2) trachydacite-trachyandesites of extrusions; (3-4) the early stage of areal volcanism: (3) trachybasalts, (4) amphibole andesite-basalts of cinder cones; (5-7) the middle stage of areal volcanism: (5) hawaiites, (6) mugearites, (7) andesitebasalts; (8-11) the late stage of areal volcanism: (8) trachybasalts, (9) hawaiites, (10) mugearites, (11) andesite-basalts. I-V fields of rock associations (see explanations in text). For (a) and (b) the scale is logarithmic, for (c) and (d) it is ordinary. Fields of compositions of different rocks groups (d) are given in accordance with [Petrograficheskii ..., 2009]. Numbers of samples mentioned in text are given.

as vanishing altogether in trachyandesites. The magnesian numbers $(\mathrm{Mg} \#)$ of olivine from phenocrysts vary between $\mathrm{Fo}_{84}$ and $\mathrm{Fo}_{63}$; the varieties with $\mathrm{Fo}_{83-79}$ form a separate group (Fig. 4, samples 144 and 141), which doesn't fit the general band of dependence for the earliest generations of olivine as functions of magnesian numbers of host rocks. On the MnO-Fo diagram (Fig. 5a) very few of the most magnesian generations occur in the field of the calc-alkaline series and correspond to the trend of normal crystallization differentiation. For most compositions, the concentration of magganese in olivine increases as the magnesian number of olivines and the alkalinity and fluid saturation of rocks increase, with the concentration even exceeding that for the alkaline varieties of rocks on Belogolovskii Volcano.
Clinopyroxene is mostly augite with $\mathrm{Mg} \#=82-68$ in trachybasalts (Fig. 6, samples 136, 141, 144, and

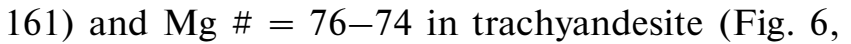
sample k46), but this parameter doesn't correlate with the magnesian number of the host rock. The anomalous samples are 141 and 144, whose pyroxenes in terms of magnesian number are the same as olivines of the first generations before them. For clinopyroxenes (and especially for orthopyroxenes) a peak of $\mathrm{MnO}$ concentration is noted independently of iron content in minerals (Fig. 5b). The trend of the direct correlation $\mathrm{TiO}_{2}-$ $\mathrm{Al}$ and $\mathrm{TiO}_{2}-\mathrm{F} / \mathrm{FM}$ (Figs. 7a, 7b) is complicated by a "cloud" of figurative points in some trachybasalts in the area of high $\mathrm{TiO}_{2}$ (sample 141), i.e., in the same rock varieties with anomalous $\mathrm{Mg}$ numbers of olivines and pyroxenes. These deviations from the common trend of 
(a)

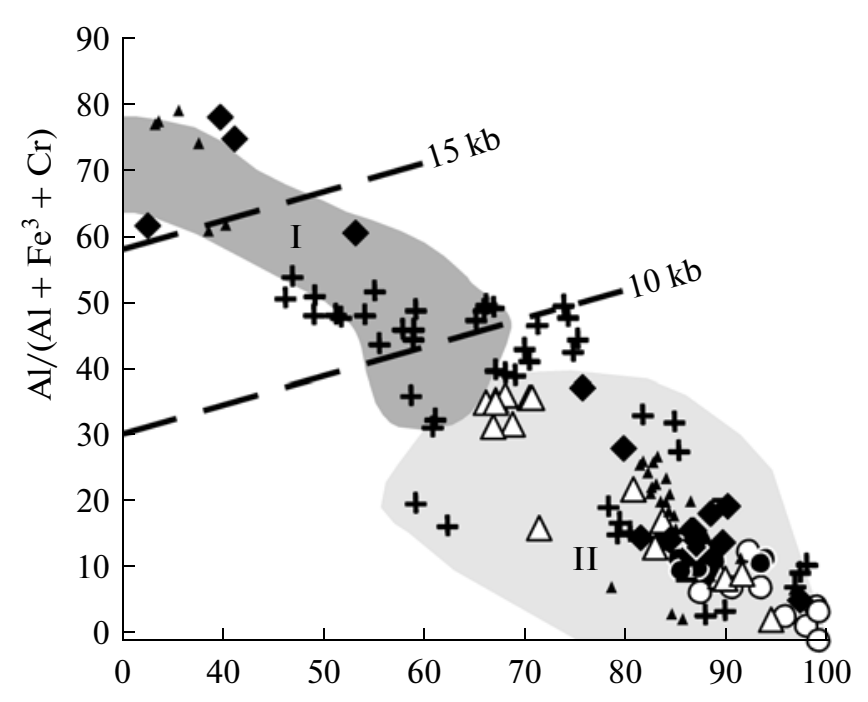

(c)

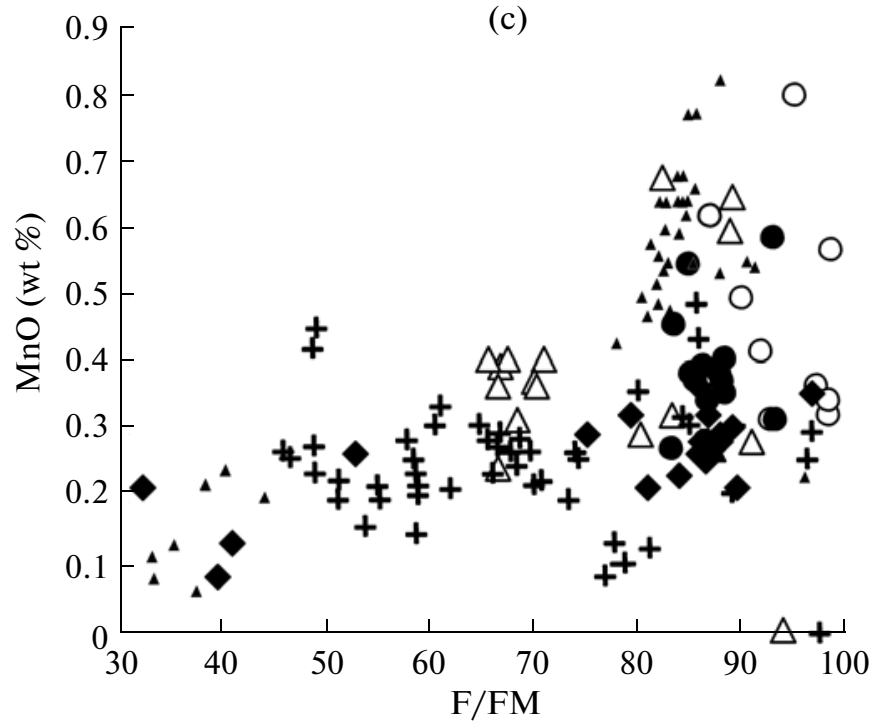

(b)

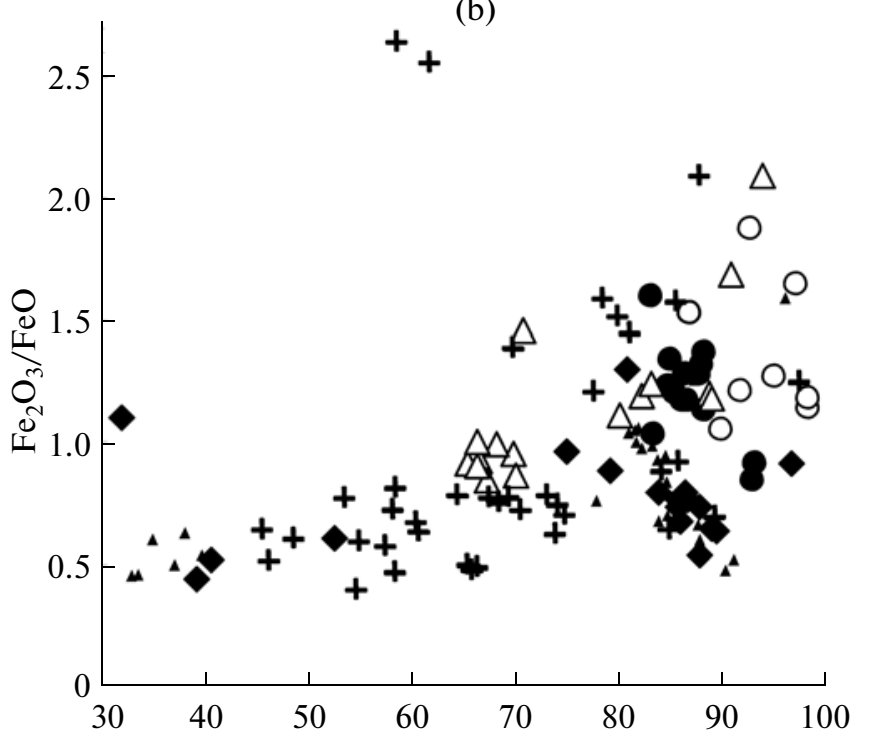

(d)

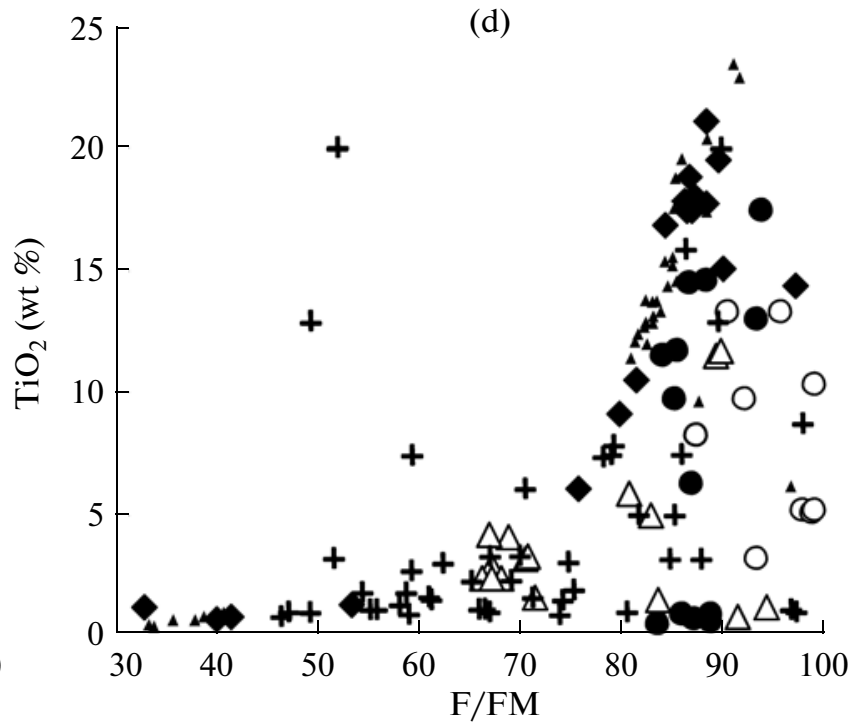

$01 \bullet 2+3 \Delta 4 \Delta 5 \bullet 6$

Fig. 3. Diagram of the spinellide compositions from Kekuknai rocks in the following coordinates: $\mathrm{Al} /\left(\mathrm{Al}+\mathrm{Fe} \mathrm{e}^{3}+\mathrm{Cr}\right)-\mathrm{F} / \mathrm{FM}(\mathrm{a})$, $\mathrm{Fe}_{2} \mathrm{O}_{3} / \mathrm{FeO}-\mathrm{F} / \mathrm{FM}$ (b), $\mathrm{MnO}-\mathrm{F} / \mathrm{FM}$ (c), $\mathrm{TiO}_{2}-\mathrm{F} / \mathrm{FM}$ (d). (1) Trachybasalts of the pre-caldera stage, andesites of extrusion; (2-3) trachybasalt association of the early stage of areal volcanism: (2) rocks of neck (sample k53), (3) rocks of flow and cinder cone (samples 49058, k57, k50); (4-5) the middle stage of areal volcanism: (4) hawaiites, (5) andesite-basalts and mugearites; (6) the late stage of areal volcanism (trachybasalts, andesite-basalts, mugearites). $\mathrm{Al} /\left(\mathrm{Al}+\mathrm{Fe}^{3}+\mathrm{Cr}\right.$ ) in atomic units, $\mathrm{Fe}_{2} \mathrm{O}_{3} / \mathrm{FeO}_{\text {in }}$ wt $\%$, $\mathrm{F} / \mathrm{FM}$ iron content (Fe/Fe $+\mathrm{Mg}$ in atomic units). (a) Fields of compositions of spinellides in basalts of intraplate (I) and island-arc (II) types are indicated. The supposed boundaries of barophilic fields are given after [Koloskov et al., 2001].

direct correlation did not result from different $\mathrm{TiO}_{2}$ contents in the rock itself: $\mathrm{TiO}_{2}=0.94$ (sample 141) and $\mathrm{TiO}_{2}=1.08$ (sample 161).

In terms of iron content $\left(f_{38.6-20}\right)$ orthopyroxene is consistent with hypersthene. Its composition also doesn't correlate with the magnesian number of the rocks (Fig. 6).

The plagioclase composition varies from $\mathrm{An}_{83}$ to $\mathrm{An}_{8}$ in trachyandesites and from $\mathrm{An}_{88}$ to $\mathrm{An}_{8}$ in trachybasalts
(Table 1). The maximum content of An in the mineral reaches the level of the compositions of the alkaline rocks that were erupted by Belogolovskii Volcano (Fig. 8a).

Trachyandesites and trachydacites in the extrusions of caldera generation stage. The following petrographic varieties are recognized: more basic olivine-bearing bipyroxene and pyroxene-hornblende trachyandesites; hornblende acid trachyandesites and biotite-hornblende trachydacite. All these varieties are of series-por- 


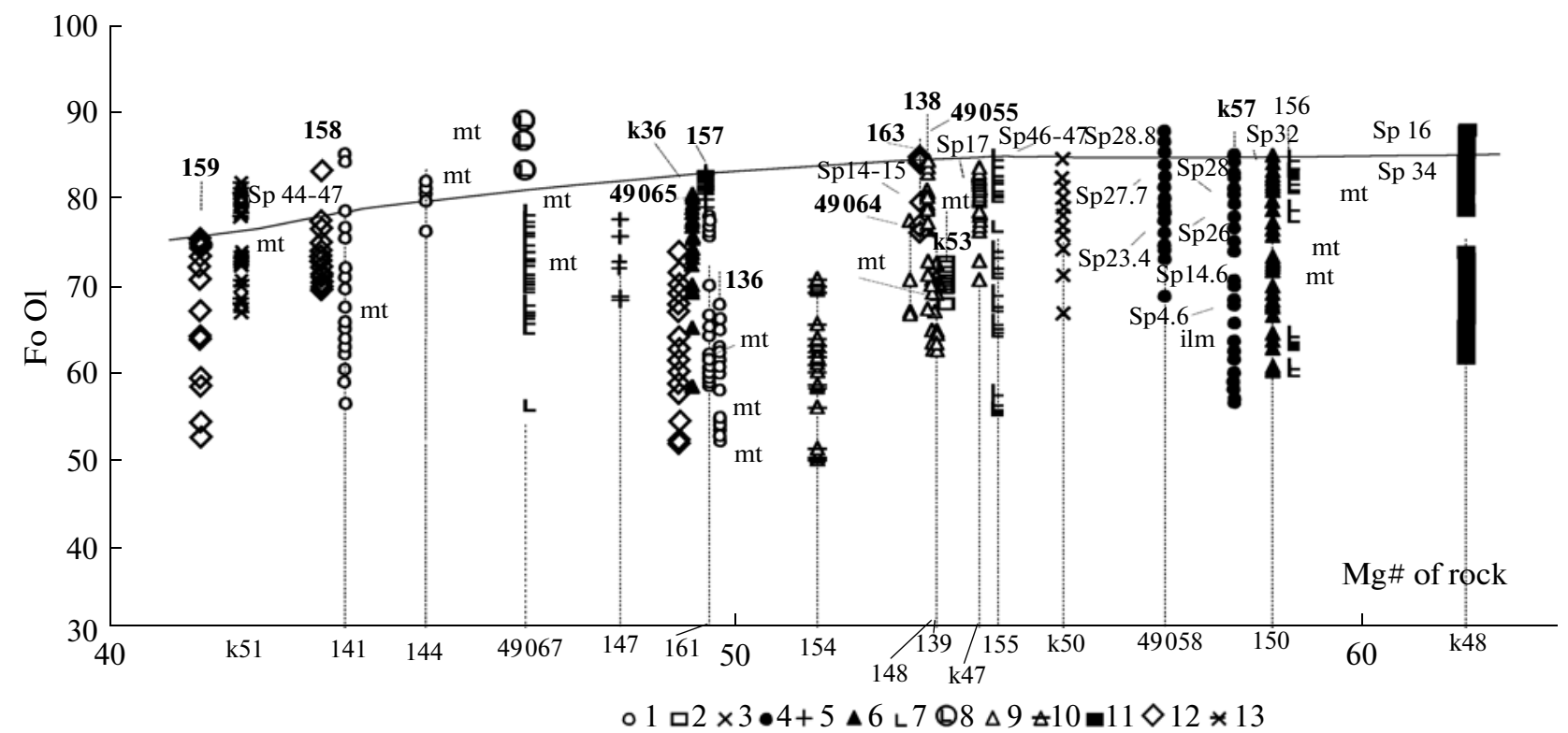

Fig. 4. Relationships between the Fo content of olivine and $\mathrm{Mg}$ number of the host rocks of Kekuknai massif.

Fo, the content of forsterite molecule in olivine $(\%), \mathrm{Mg} \#=\mathrm{Mg} /(\mathrm{Mg}+$ total $\mathrm{Fe})$, where total $\mathrm{Fe}=\left(\mathrm{Fe}_{2} \mathrm{O}_{3} \times 0.8998+\right.$ $\mathrm{FeO}) / 71.85 \times 1000$.

$\underline{\mathrm{Sp}}_{44-47}$, marked Fo in the host olivine with spinel inclusions that contain 44-47 wt \% $\mathrm{Al}_{2} \mathrm{O}_{3}$, mt, marked Fo in the host olivine.

(1) Pre-caldera stage (trachybasalts of the shield-shaped edifice); (2-5) the early stage of areal volcanism: (2-4) trachybasalt association, rocks of: (2) neck (sample k53), (3) cinder cone (sample k50); (4) flows (samples 49058, k57), (5) amphibole andesitebasalts of cinder cones; (6-10) the middle stage of areal volcanism: (6-8) hawaiites: amphibole-less (6), amphibole (7), in zone of amphibole disintegration (8), (9) andesite-basalts, (10) mugearites; (11-13) the late stage of areal volcanism: (11) trachybasalts, (12) mugearites, (13) andesite-basalts (sample k51). The sample numbers tally with those given in Fig. 2. The solid line shows the boundaries of initial compositions of olivines for most of the rock varieties.

phyric texture and trachytoid microtexture of the groundmass. The fraction of phenocrysts varies between $15-25$ and $40 \mathrm{vol} \%$. Phenocrysts $3 \mathrm{~mm}$ across and subphenocrysts are composed of plagioclase, pyroxene, amphibole (pargasite), and titanomagnetite at variable ratios between the mineral phases, but are invariably dominated by plagioclase. Olivine occurs in basic andesites and biotite in trachydacites. The basic varieties are characterized by gabbroid and more rarely by fine-grained pyroxenite microinclusions. Microlites in the groundmass are plagioclase (andesine-oligoclase), orthopyroxene, and magnetite; apatite is also found. Clinopyroxene occurs in basic andesites only. The interstices are composed of a quartz (?)-feldspar microcrystalline aggregate. Plagioclase compositions in trachyandesites vary from $\mathrm{An}_{64}$ to $\mathrm{An}_{45.2}$. These are the values closest to the calculated compositions (Table 1) and to the average compositions for calk-alkaline series (Fig. 8, sample 135). One characteristically observes zonality (direct, iterative, and spotted) with resorbed nuclei of crystals. Hornblende is always opacitized to some degree; its phenocrysts are often corroded by the groundmass. The iron content in clinopyroxenes $\left(f_{24-31.3}\right)$ and orthopyroxenes $\left(f_{26.3-31.3}\right)$ is practically the same and doesn't differ from similar characteristics of trachyandesites in the volcano edifice (Table 1).

Areal trachybasalts are the most abundant at the early stage of post-caldera volcanism (Fig. 1a, association III). They are found in pyroclastics of cinder cones (samples 49057 and k50), lava flows (samples k57 and 49058), and necks (sample k53). The groundmass textures differ in correspondence with the facial affinity of rocks: from hyalopilitic with cryptocrystalline glass in cinders, pilotaxitic with crystallized micro-grained feldspar matrix in interstices between fluidly arranged plagioclase and $\mathrm{K}-\mathrm{Na}$ feldspar microlites in lava flows, to micro-doleritic in the neck. The common set of phenocrysts and sub-phenocrysts includes olivine and clinopyroxene; plagioclase is found in much lower amounts; in phenocrysts it is often absent. Orthopyroxene occurs in trachybasalts of the neck only. In samples from cones and flows olivine (as well as clinopyroxene) contains inclusions of chrome-aluminous spinel and titanomagnetite; in the neck rocks it bears only titanomagnetite inclusions (Fig. 2). The groundmass basis contains K-feldspar. It is significant that areal trachybasalts contain K-feldspars mostly not in granophyric aggregates of interstitial space as in hawaiites, but rather 


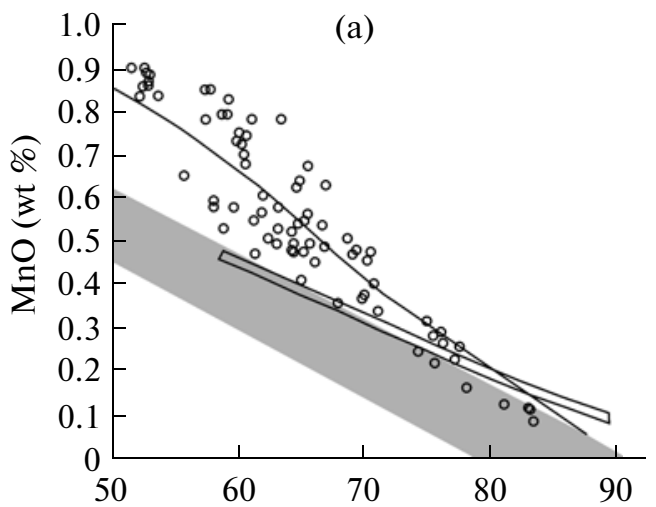

(c)
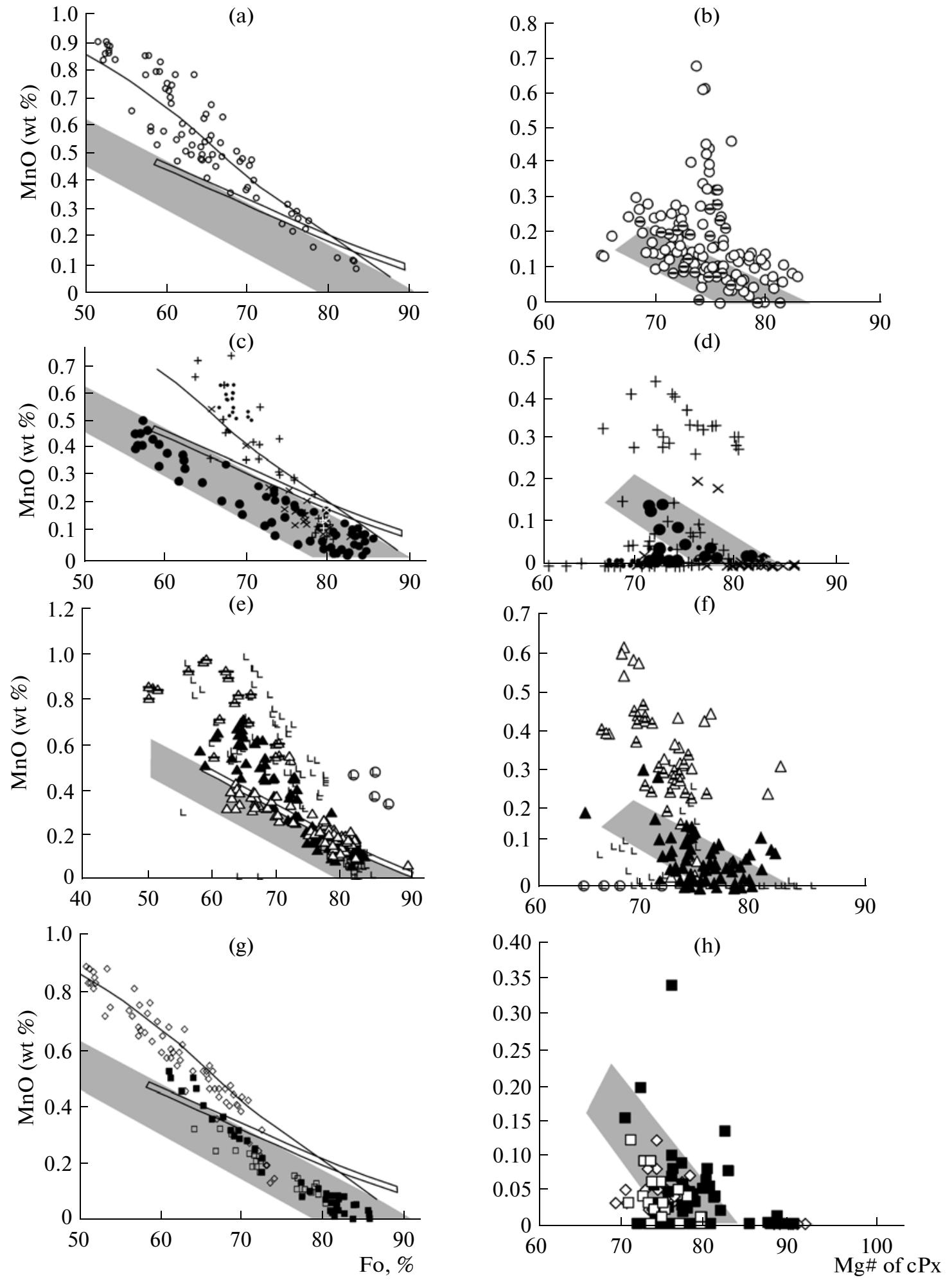

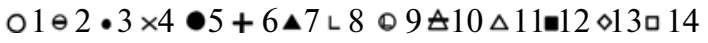

Fig. 5. The MnO-Fo ratios in olivines and $\mathrm{MnO}-\mathrm{Mg}$ \# in clinopyroxenes of the Kekuknai massif. (a)-(b) Pre-caldera stage: (1) trachybasalt of the shield-shaped volcano edifice, (2) trachyandesites of extrusions; (c) -(d) the early stage of areal volcanism: (3-6) trachybasalt association, rocks of: (3) neck (sample k53), (4) cinder cone (sample k50), (5) flows (samples 49058, k57), (6) amphibole andesite-basalt of cinder cones; (e)-(f) the middle stage of areal volcanism: (7-9) hawaiites: amphibole-less (7), amphibole (8), in the zone of amphibole disintegration (9), (10) mugearites, (11) andesite-basalts; (g) - (h) the late stage of areal volcanism: (12) trachybasalts, (13) mugearites, (14) andesite-basalts (sample k51). The filled field represents compositions of olivines of trachybasalt associations of the early stage of areal volcanism, unfilled area is for rocks of various regions from [Volynets et al., 1975]. Solid line separates extreme MnO contents in olivines of alkaline rocks of Belogolovskii volcano (see explanations in the text). 


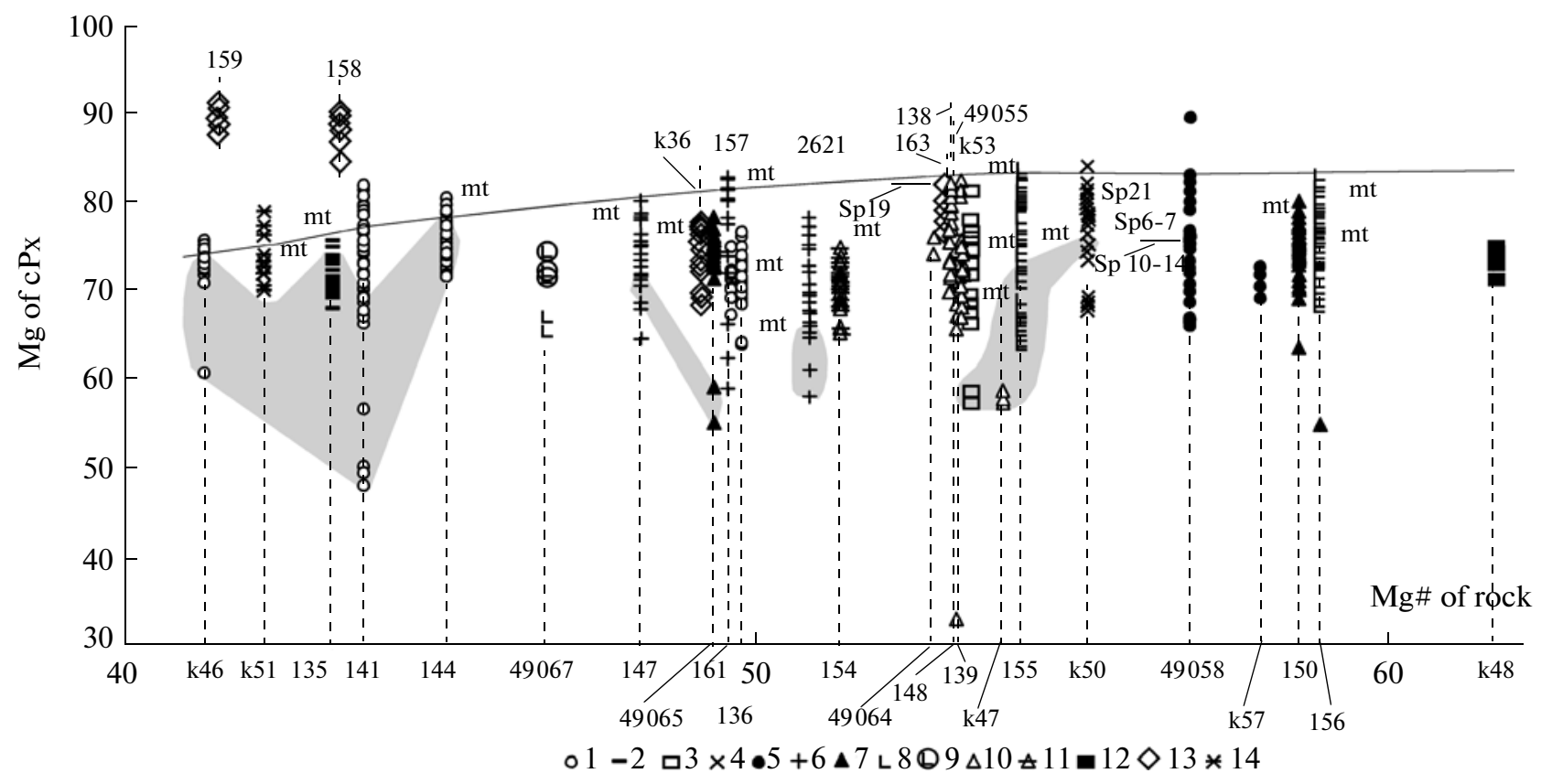

Fig. 6. The relation between the magnesian number of pyroxene ( $\mathrm{Mg} \#$ of Px) versus the magnesian number (Mg \# of rock) for Kekuknai volcanic rocks.

$\mathrm{Mg} \#$ of $\mathrm{Px}-\mathrm{Mg} / \mathrm{Fe}$ (total) in vol \%, Mg \# of rock is that in Fig. 4. (1-2) pre-caldera stage and extrusions: (1) trachybasalts of shieldshaped volcano edifice, (2) trachyandesites of extrusions; (3-6) the early stage of areal volcanism: (3-5) trachybasalt association, rocks of: (3) neck (sample k53), (4) cinder a cinder cone (sample k50), (5) flows (samples 49058, k57), (6) amphibole andesitebasalts of cinder cones; (7-10) the middle stage of areal volcanism: (7-9) hawaiites: amphibole-less (7), amphibole (8), in the zone of amphibole disintegration (9), (10) andesite-basalts; (11) mugearites; (12-14) the late stage of areal volcanism: (12) trachybasalts, (13) mugearites, (14) andesite-basalts (sample k51).

$\underline{\mathrm{Sp} 10.45}$ and $\mathrm{mt}$ are the same as in Fig. 3 relative to the magnesian number of pyroxene. The solid line shows the boundary of the magnesian number (Fo \%) for initial olivine compositions in the same samples. The stippled background designates the field of orthopyroxene compositions. Sample numbers tally with those in Fig. 2.

it composes a considerable portion of the feldspar microlites.

In general, the olivine composition in trachybasalts varies from $\mathrm{Fo}_{86}$ to $\mathrm{Fo}_{56}$ (Table 1) and doesn't correlate with the $\mathrm{Mg}$ number of the host rocks. In flows (sample 49058, k57) they have the highest $\mathrm{Mg}$ number with a wide range of compositional variation $\left(\mathrm{Fo}_{86-68}\right)$. Here, a well-expressed negative Fo$\mathrm{MnO}$ correlation is observed (Fig. 5c) with a low level of $\mathrm{MnO}$ accumulation, which corresponds to the relatively low total alkalinity of these rocks (Fig. 2d). The level of variation for the relevant characteristics is highlighted as a separate field to be compared with the other compositions. The most crystallized and fluid-saturated neck rocks (sample k53) have olivine compositions that vary in a narrow range $\left(\mathrm{Fo}_{71-67}\right)$ but they have remarkably high $\mathrm{MnO}$ concentrations (Fig. 5b). The cone trachybasalts (sample $\mathrm{k} 50$ ) have a narrower range of olivine compositional variation $\left(\mathrm{Fo}_{81-66}\right)$, although the $\mathrm{MnO}$ content is also high.

Clinopyroxenes (corresponding to salite-augite in composition) from trachybasalts of the cone, flow, and neck have similar magnesian numbers $(\mathrm{Mg} \#=84-66)$, while their first generations correspond to the Mg number of olivines (Fig. 6, samples k50, 49058, k53) from the same samples. It is worth noting that clinopyroxenes from the cone trachybasalts for most of the compositions are more aluminous (Fig. 7c, sample k50) and those from the neck trachybasalts have higher titanium contents (Fig. 7c, sample k53). The average level of the An content in the earlier generations of plagioclase is slightly below the boundary of alkaline rocks of Belogolovskii volcano; this is especially true for the neck (Fig. 8b), which corresponds to the low total alkalinity of analyzed trachybasalts (Fig. 2d).

Andesite-basalts of cinder cones. Here, we consider the intermediate group of andesite-basalts (group II on $\mathrm{Nb}-\mathrm{K}$ diagram, Fig. 2a), which were identified as belonging to the early stage of areal volcanism, although a large part of the rocks of this type occur in associations of the middle and late stages.

These are sparsely fine-porphyritic rocks with phenocryst below 6 vol $\%$ and less than $1 \mathrm{~mm}$ across. The groundmass microtexture is hyalopilitic or hyalopilotaxitic. Glomeroporphyric aggregates $3 \mathrm{~mm}$ across are found; fine-grained segregations of olivine pyroxenites are characteristic and sometimes the microtexture con- 

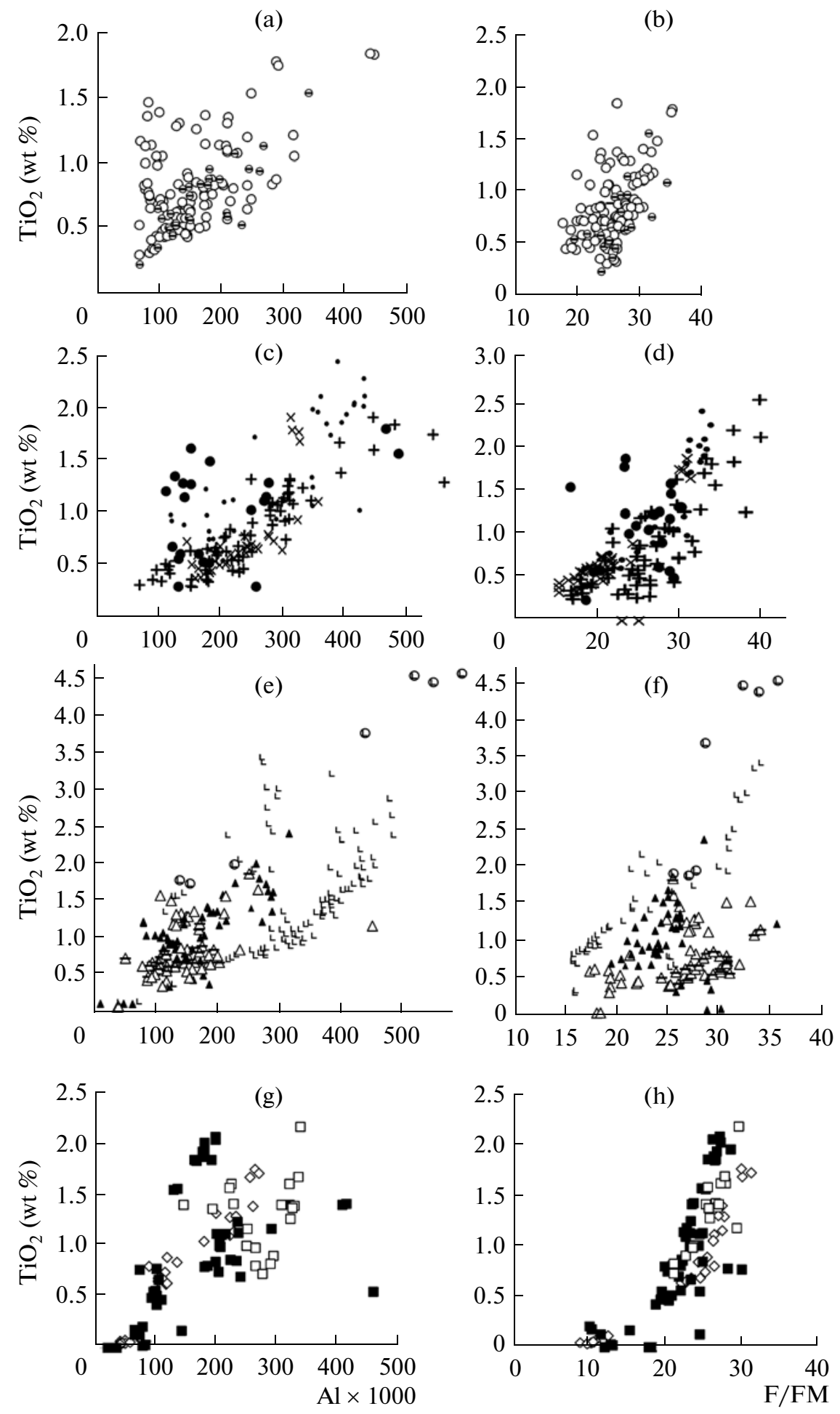

$01 \oplus 2 \cdot 3 \times 4 \bullet 5+6 \wedge 7\llcorner 8 \bullet 9 \Delta 10 \Delta 11 \bullet 12 \diamond 13 \square 14$

Fig. 7. The $\mathrm{TiO}_{2}-\mathrm{Al}$ and $\mathrm{TiO}_{2}-\mathrm{F} / \mathrm{FM}$ ratios in clinopyroxenes from Kekuknai massif rocks. (a) $-(\mathrm{h})$ and $1-14$ are the same as in Fig. 5.

$* \mathrm{Al}$ - The element is calculated as the cationic value from the structural formulae of the clinopyroxenes.

tains plagioclase. Plagioclase, clinopyroxene, olivine, and orthopyroxene occur in phenocrysts and sub-phenocrysts; relic pargasite or products of its disintegration are always observed. This disintegrated amphibole (apo-amphibole) (Fig. 9c) is an amphibole crystal that completely decomposed to form a fine-grained polym- 


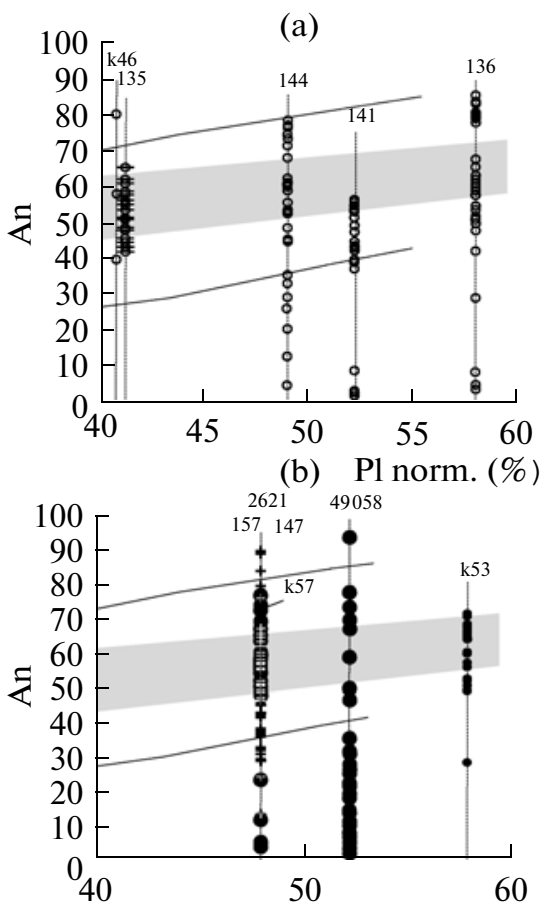

(c) Pl norm. (\%)
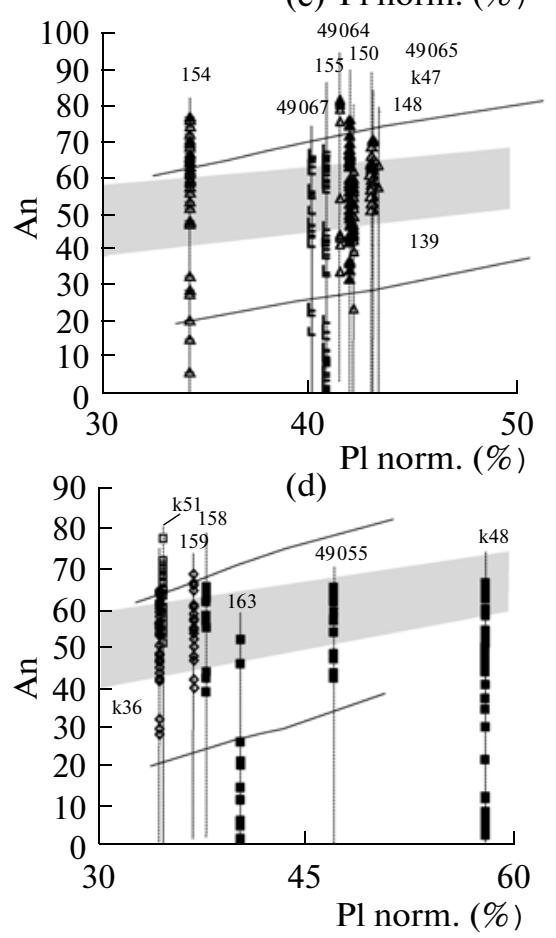

$01 \bullet 2 \cdot 3 \times 4 \bullet 5+6 \Delta 7\llcorner 8 \triangleq 9 \Delta 10 \bullet 11 \diamond 12 \square 13$

ineral aggregate: amphibole + plagioclase + titanomagnetite + clino- and orthopyroxene + glass. The presence of this aggregate attests to the increasing disequilibrium of amphibole with melt; its disintegration is possibly connected to an increase of the oxidation potential of oxygen due to the changed thermodynamic conditions of crystallization. The groundmass contains plagioclase, clinopyroxene, and magnetite microlites,
Fig. 8. The ratio of modal (An) and normative (no. Pl norm.) plagioclase compositions from Kekuknai massif. Stages of volcanism: (a) pre-caldera and extrusions, (b) the early, (c) the middle, (d) the late stage of areal volcanism. (1-8) the same as in Fig. 5; (9) mugearites, (10) andesite-basalts; (11-13) the late stage of areal volcanism; (11) trachybasalts, (12) mugearites, (13) andesitebasalts (sample k51).

The stippled background marks the fields of plagioclase phenocrysts from Quaternary volcanic rocks of the calcalkaline series of Kamchatka, after [Volynets and Koloskov, 1976]. The solid lines enclose the compositions of the alkali basaltoids of the Belogolovskii volcano. For explanations, see the text. The plagioclase compositions are given in An molecule content (\%).

usually olivine, and rarely alkaline feldspar. The glass is usually cryptocrystalline, overfilled with crystallites, rarely fresh and brownish.

The maximum $\mathrm{Mg}$ number of olivine from andesitebasalts: $\mathrm{Fo}_{81-78}$ is higher than the same characteristic in basalts with the highest $\mathrm{Mg}$ numbers in the edifice: $\mathrm{Fo}_{78-75}$ at practically the same $\mathrm{Mg}$ numbers in host rocks (Fig. 4, samples 157 and 161) but also the same as in "anomalous" sub-liquidus olivine from trachybasalt of the shield-shaped volcano (Fig. 4, sample 144). The same may be claimed in relation to clinopyroxenes, although the range of compositional variation of this mineral in andesite-basalt is much broader (Table 1, Fig. 6). Both the olivines and clinopyroxenes of this rock group are characterized by high $\mathrm{MnO}$ contents (Fig. 5c and 5d). Clinopyroxenes of andesite-basalts and trachybasalts are similar in their concentrations of $\mathrm{TiO}_{2}$ and $\mathrm{Al}$, but the former differ in a higher $\mathrm{Fe}$ content (Fig. 7d). Olivine (sample 157, $\mathrm{Fo}_{80}$ ) was found to contain an inclusion of high-aluminous $\left(\mathrm{Al}_{2} \mathrm{O}_{3}=12.0\right)$ and high-titanium $\left(\mathrm{TiO}_{2}=1.8\right)$ clinopyroxene, along with a melt inclusion of complex compositions that consist of andesite glass + high-aluminous $\left(\mathrm{Al}_{2} \mathrm{O}_{3}=16.9-19.7\right)$ and high-titanium $\left(\mathrm{TiO}_{2}=1.9-2.2\right)$ clinopyroxene.

The basicity of plagioclases from andesite-basalts varies: $\mathrm{An}_{89-32}$ (Table 1). These are the most anomalous compositions compared to those calculated (Fig. 8, samples 147, 157, 2621). Along with fresh bytownite, reverse-zoning plagioclase phenocrysts with acid sponge nuclei and inversion zones overfilled by glassy microinclusions are sometimes observed.

Hawaiites are the dominant rock type of the middle stage of areal volcanism (Fig. 2a, field IV), although some scattered compositions of this type are also observed at the late stage.

Usually, these are sub-aphyric or rarely fine-porphyritic rocks. Relatively large phenocrysts are not numerous. The fraction of phenocrysts (up to $1.5-2 \mathrm{~mm}$ across) is not more than 5-6 vol \%. The groundmass textures are diverse and depend on the facial affinity of the rock. 

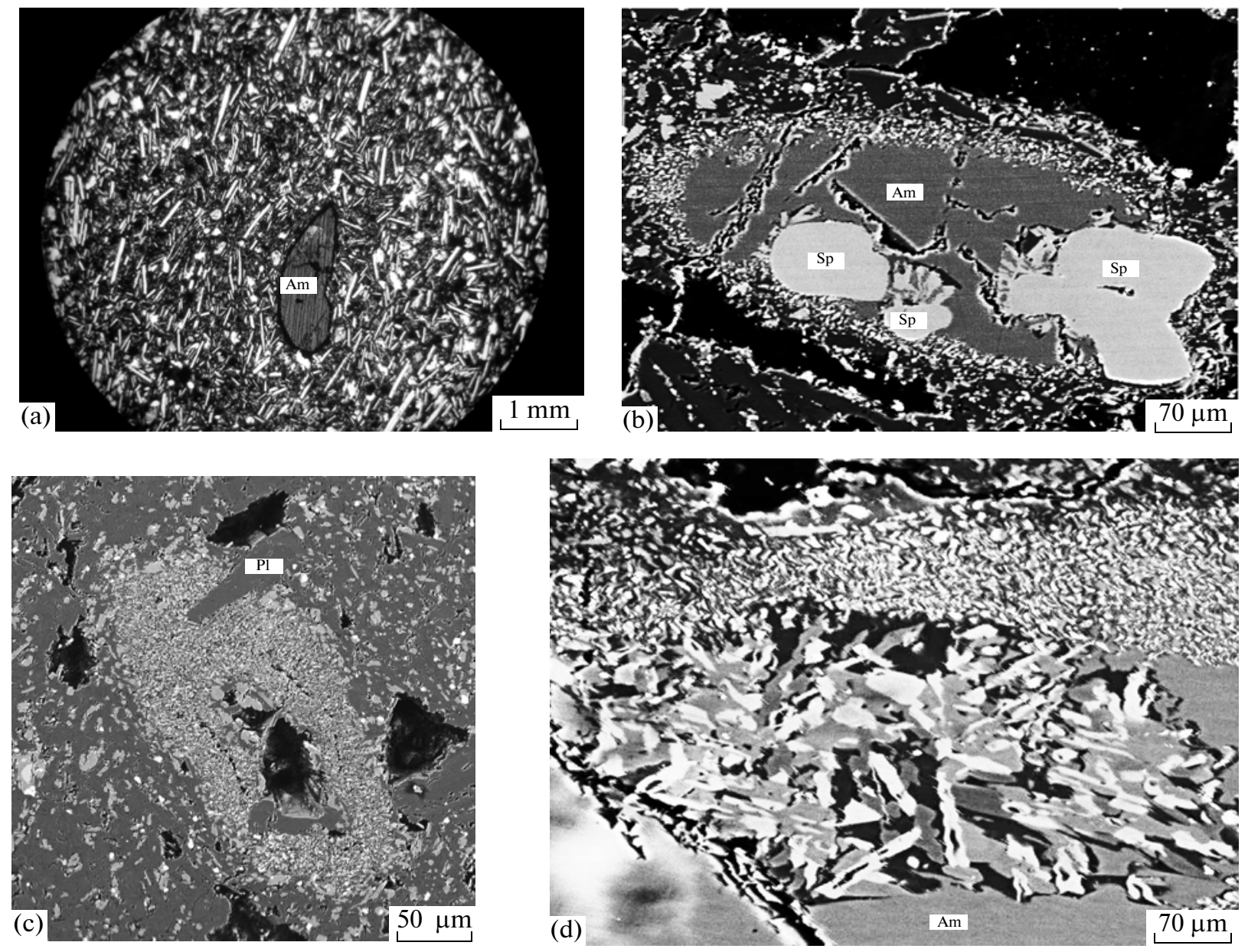

Fig. 9. Different-scaled images of amphiboles and its relic aggregates in Kekuknai rocks. (a) Amphibole phenocryst with a reaction rim (microphoto in crossed nicols); (b) a rare case of a high-alumina spinel inclusion in amphibole; (c) disintegrated apo-amphibole; (d) fragment of reaction rim and a segment of amphibole disintegration (plagioclase, clinopyroxene, olivine, rhonite, magnetite, glass, secondary amphibole). (a), (b), (d) in hawaiite (sample 49067), (c) in andesite-basalt (sample 147). (a), (b), (d) images in back-scattered electrons.

Microdoleritic, intersertal, pilotaxitic, fluidal, and hyalopilitic microtextures are observed. The first are found in rocks from dykes and flows; the last is typical of cinder and bombs.

In quantitative terms, olivine dominates among phenocrysts and sub-phenocrysts, clinopyroxene, and plagioclase are much less abundant. Phenocrysts of opacitized (sometimes dissociated) amphibole (pargasite) (Fig. 9a, b, d) also occur. Zonal amphibole phenocrysts with an opacite rim were discovered in chilled microporous pyroclastics of semi-destroyed cones (sample 49066, 49067). Shadow forms of hornblende dissociation are found in hawaiites of the neck and the dyke (samples 156, 155). Rocks from dykes and necks also have other distinguishing features. They typically involve increasing $\mathrm{Fe}$ content in marginal zones of relatively large phenocrysts of olivine and clinopyroxene, the presence of olivines resorbed by groundmass, higher crystallinity due to a significant quantity of sub-phenocrysts, and the occurrence of various glomeporhyritic aggregates and inhomogeneities (microinclusions of olivine dolerites and olivine pyroxenites). There are also xenocrysts of acid plagioclase with inversion zones overfilled with apo-glassy microinclusions (sample 156), as well as xenocrysts of olivine with hypersthene rims and of quartz in the pyroxene fringe. The early crystallization of aluminous spinel typically occurs in hawaiites (Figs. 3 and 9b). Spinels with the highest alumina content were found in magnesian olivines $\left(\mathrm{Fo}_{83-85}\right)$ from the neck and the dyke (Fig. 4, samples 155 and 150). The groundmass contains magnetite.

Olivines of amphibole-less hawaiites and areal trachybasalts are close in $\mathrm{Mg}$ number and lie in the field of the Fo-MnO correlative dependence. However, olivine from amphibole hawaiites deviates notably to a higher Mn content, even in magnesian compositions, overlapping the boundary of the same mineral from the alkaline rocks of Belogolovskii volcano (Figs. 5c, 5e). Olivines that originated from the disintegration of amphibole 


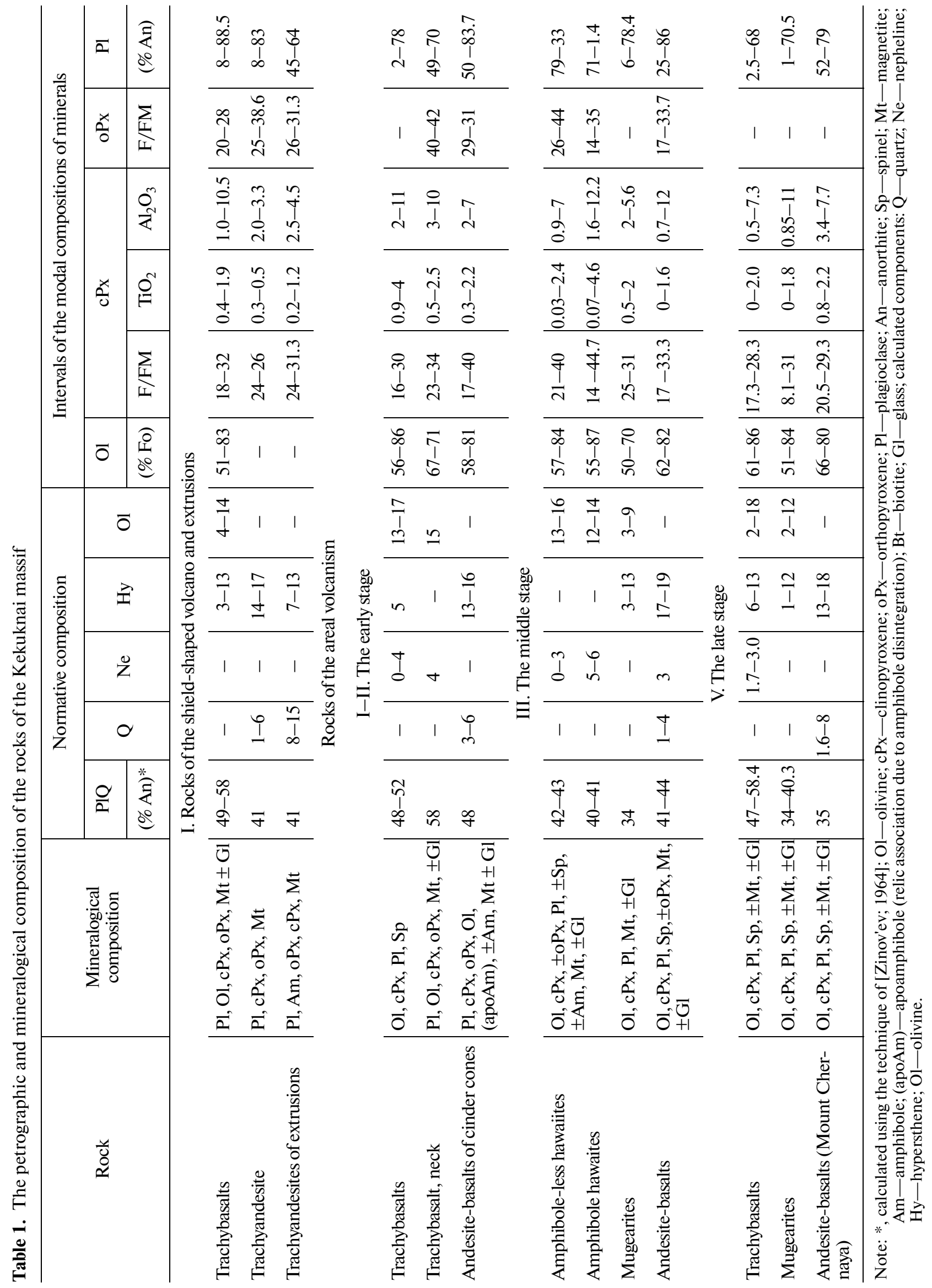


phenocrysts (in paragenesis with magnetite) are characterized by very high $\mathrm{Mg}$ numbers (up to $\mathrm{Fo}_{88-84}$ ) and high $\mathrm{MnO}$ content (Fig. 5e) and $\mathrm{CaO}$ (up to $0.8-1.0 \mathrm{wt} \%$ ). In this, they differ significantly from olivines in trachybasalts, in which an anomalous Mn-content is noted in the neck only.

Clinopyroxenes of hawaiites and areal trachybasalts do not practically differ in $\mathrm{Mg}$ \# and $\mathrm{MnO}$ concentrations (Figs. 5d and 5f). Clinopyroxenes of amphibole hawaiites, in contrast to amphibole-less varieties, are characterized by notable enrichment in $\mathrm{Al}$ and $\mathrm{TiO}_{2}$ (Figs. 7e and 7f). High Ti-content sometimes correlates with high concentrations of this element in host rock. But some moderately Ti-containing hawaiites (with phenocrysts of Ti-amphibole) may also contain clinopyroxenes with especially high $\mathrm{TiO}_{2}$ contents. Plagioclases from hawaiites typically have substantially lower normative compositions, although their sub-liquidus generations are rich in anorthite molecules (Fig. 8c). At least three generations of plagioclase from the neck are identified (Fig. 8c, sample 155).

Mugearites are abundant to the same extent both at the middle and the late stages of areal volcanism (Fig. 2a, fields IV-V). Therefore they are described jointly. They differ from hawaiites, first of all by the fact that their normative composition does not contain nepheline and hypersthene appears, although no modal orthopyroxene is found. The rocks are usually sub-aphyric; fine-sparsely-porphyritic varieties are encountered. Groundmass textures are series-porphyritic, microdoleritic, and pilotaxitic. Sub-phenocrysts are dominated by plagioclase, but olivine and clinopyroxenes are also noted. Microlites of olivine, clinopyroxene, plagioclase, titanomagnetite and of alkali feldspar occur in the groundmass; K-feldspar is present in the basis. Crystallization of mugearite minerals took place in paragenesis with magnetite, although one of the samples of the late stage (sample k36/1) was found to contain inclusions of chrome-aluminous spinel in olivine. In spite of the fact that the range of compositional variation (Fo) in olivines from mugearites, hawaiites, and trachybasalts is largely the same, the first ones are very similar to olivines from the trachybasalts of the pre-caldera edifice (Figs. 4, 5a, 5e, 5g) (Figs. 10a, $10 \mathrm{e}, 10 \mathrm{~g})$, viz., maximum ferruginous compositions, maximal enrichment in $\mathrm{MnO}$, and low $\mathrm{CaO}$ content in the area of ferruginous generations. The same may be noted with respect to clinopyroxenes: in general they are more ferruginous, with higher $\mathrm{MnO}$ contents and lower $\mathrm{TiO}_{2}$, differing from pyroxenes of trachybasalts and hawaiites but approaching the mineral compositions of trachybasalts in the edifice (Figs. 4, 5b, 5f, 5h, $7 \mathrm{~b}, 7 \mathrm{f}, 7 \mathrm{~h})$. Some mugearites of the late stage are characterized by anomalously magnesian generations of pyroxene (Fig. 6, samples 158, 159). But such magnesian pyroxenes (as well as olivines) are also observed in andesite-basalts of this stage (Mount Chernaya). The causes of these deviations will be considered later when the results are discussed.

The normative compositions of plagioclases from mugearites are consistent with andesines, but their modal compositions are remarkable for much higher An contents. It is of interest that similar deviations are also observed in mugearite samples of the late stage and in andesite-basalts of Mount Chernaya (Fig. 8c and 8d).

Andesite-basalts of the hawaiite-mugearite association of the middle stage of areal volcanism. The rock textures are sub-aphyric, rarely low porphyritic. Relatively big phenocrysts, as large as $1.5 \mathrm{~mm}$ across, are sparse (not more than 3-5 vol \%). They are composed of olivine, clinopyroxene, more rarely orthopyroxenes; plagioclase is more common and dominates in small sub-phenocrysts. Pyroxenes sometimes overgrow around olivine grains and form aggregates between themselves. The necks (sample 139) have a large fraction (up to $40 \mathrm{vol} \%$ ) of sub-phenocrysts less $0.5 \mathrm{~mm}$ across. The groundmass of andesite-basalts in the neck (sample 139) usually displays a hyalopilitic microtexture and consists of microlites of plagioclase, orthopyroxene, clinopyroxene, olivine and cryptocrystalline glass saturated with ore dust. Flows (samples 148, 138) contain pilotaxitic and tholeiitic (microdoleritic with minor amounts of glass) microtextures and similar sets of microlites with microgranular feldspar interstitial fill.

Chrome-aluminum spinel (Figs. 3, 4, 6) occurs in magnesian orthopyroxene $(\mathrm{Mg} \#=82.4)$ of the neck (sample 139) and olivines $\left(\mathrm{Fo}_{69-66}\right.$ and $\left.\mathrm{Fo}_{81-79}\right)$ of flows (samples 148, k47). In cases of more ferruginous compositions, the crystallization of minerals takes place in paragenesis with titanomagnetite. In the center of clinopyroxene crystals from a crushed sample from lava flow rock (sample 138) and from a cinder cone (sample 49064) there is a locality whose composition is consistent with hornblende.

Compared with hawaiites and areal trachybasalts, the composition of olivines of the early stages is less magnesian $\left(\mathrm{Fo}_{82}\right.$ against $\left.\mathrm{Fo}_{85-86}\right)$. It is of interest to note that the neck olivines (Fig. 4, sample 139) show a narrower compositional range $\left(\mathrm{Fo}_{72-62}\right.$ against $\mathrm{Fo}_{82-62}$ for andesite-basalts as a whole) and in this parameter are inferior to orthopyroxene (Mg \#=84-82) (Fig. 6, sample 139).

In terms of the Fo-MnO ratio (Fig. 5e) most olivines from andesite-basalts continue the clearly expressed correlative trend of hawaiites-andesitebasalts that do not contain amphibole. The points of compositions of amphibole hawaiites and mugearites form an independent field with high $\mathrm{MnO}$ concentrations that extend beyond the boundaries of the olivine compositions in the alkaline rocks of Belogolovskii volcano. Clinopyroxenes from both andesite-basalts and 

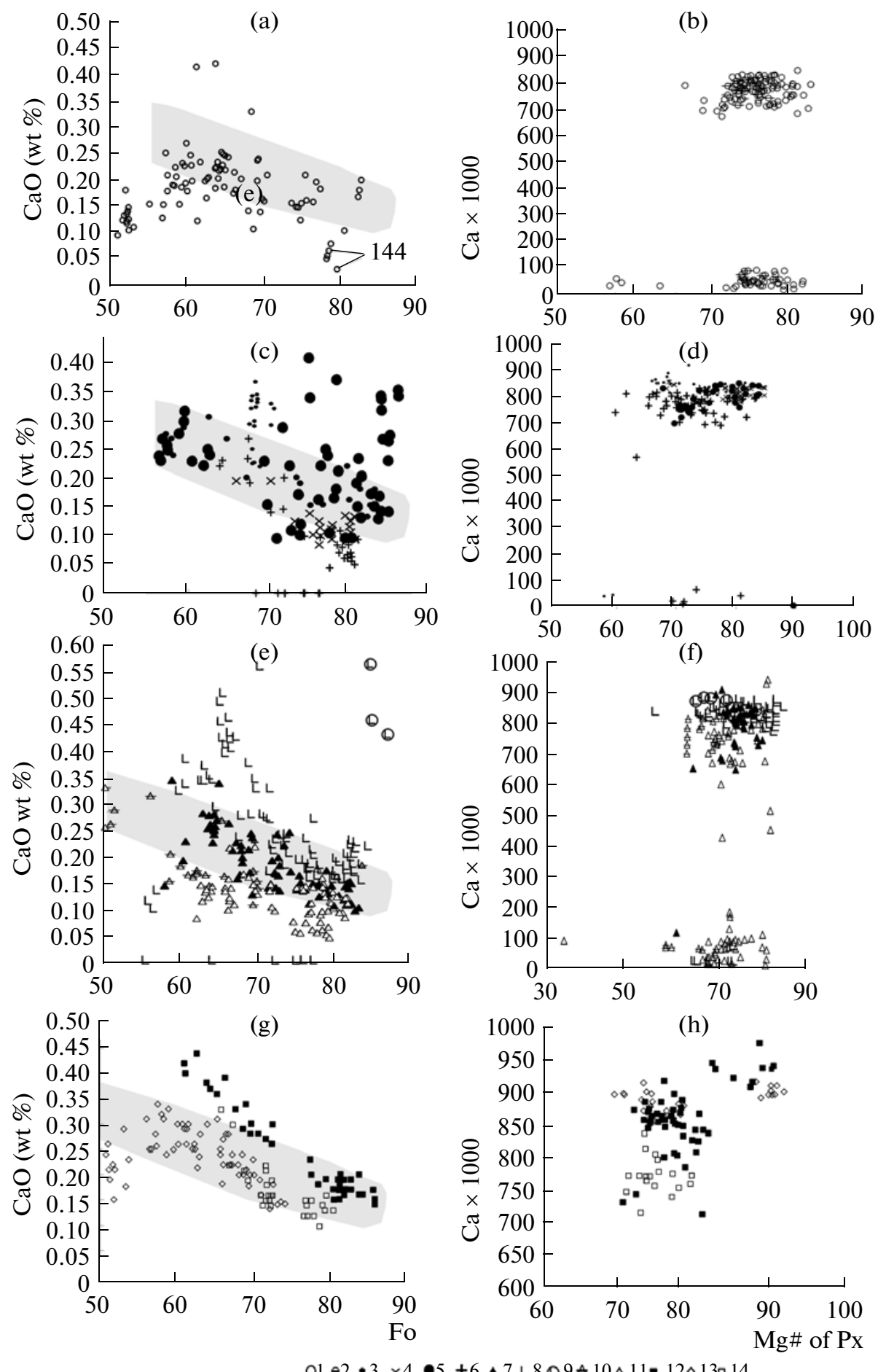

Fig. 10. Ratios $\mathrm{CaO}-\mathrm{Fo}$ in olivines ( $\mathrm{a}, \mathrm{c}, \mathrm{e}, \mathrm{g})$ and $\mathrm{Ca}-\mathrm{Mg}$ \# in clinopyroxenes (b, d, f, h) from Kekuknai massif rocks. (a) - (h) and 1-4 are the same as in Fig. 5. Ca-The element is calculated as the cationic value from the structural formulae of the clinopyroxenes.

The field of correlative compositions of olivines of trachybasalt association is highlighted.

mugearites are rich in $\mathrm{MnO}$ (Fig. 5f), much more so than the same mineral in rocks of the same name in the early stages (Figs. 5b, 5d). In terms of the $\mathrm{TiO}_{2}-\mathrm{F} / \mathrm{FM}$ ratio (Fig. 7f) clinopyroxenes from andesite-basalts occur in the same field with points for the same mineral from amphibole-less, relatively less titaniferous, hawaiites. Both of them are characterized by low aluminacontent in this mineral (Fig. 7e). The compositions of orthopyroxenes correspond to hypersthene with a content of ferrosilite minal of $18-34 \%$. The points of the 
plagioclase modal compositions lie largely in the field of this mineral sampled from alkaline rocks of Belogolovskii volcano, except for the compositions from amphibole-bearing andesite-basalt (sample 49064) with values of $\mathrm{An}_{86-84}$ (Fig. 8).

To sum up, mineral compositions in different rock types and age groups differ considerably, but necks and dykes usually stand out of the general pattern. This is explained by the fact that necks are conduits of fluid currents and dykes are remarkable for their advanced crystallization processes, which was already mentioned in the first part of the paper. This is why these phenomena are sometimes considered separately in a group of rocks of similar compositions.

The mineralogical differences are due on one hand to peculiarities of the rock compositions themselves, primarily their alkalinity (position of upper boundary of fields in diagrams of olivine and plagioclase compositions), and to a lesser extent, to $\mathrm{Mg}$ number and Ti-content (for example, high-titanium hawaiites contain clinopyroxenes with higher $\mathrm{TiO}_{2}$ concentrations).

On the other hand, one may state that increased concentrations of $\mathrm{MnO}$ with lower $\mathrm{CaO}$ contents in olivines may be considered as an indication of high oxygen fugacity, while the high contents of both $\mathrm{MnO}$ and $\mathrm{CaO}$ in olivines along with the high $\mathrm{Mg}$ numbers of mafic minerals and high concentrations of An molecule contents in plagioclase may result from high water saturation of the melts.

\section{DISCUSSION OF THE RESULTS}

\section{The Mineral Compositions of Volcanic Rocks as an Indication of their Generation Conditions (Some General Theses)}

The temperature dependence of varying mineral compositions in magmatic rocks is most often applied for the identification of crystallization differentiation trends in the respective melts. We will estimate this factor in the first instance during a subsequent analysis of the data. The existing conception on the significant barophilic character of spinels (especially their highalumina varieties) compared with titanomagnetites allows one to distinguish associations whose crystalline phases begin to appear at different depths (Fig. 3a) [Koloskov et al., 2001]. On the other hand, the appearance of titanomagnetites indicates a shallow-depth and substantially oxidation environment of rock generation; as well, the generation of spinels testifies to highly reducing conditions. As seen in Fig. 3, at values of F/FM $>80$ a sharp increase of oxidation degree takes place in a large group of titanomagnetites. It is a significant fact that the same compositions show the same sharp increase in $\mathrm{MnO}$ and $\mathrm{TiO}_{2}$ contents. It may be supposed that a similar dependence can be seen in the composition of other minerals (for $\mathrm{MnO}$ in olivines, for
$\mathrm{MnO}$ and $\mathrm{TiO}_{2}$ in clinopyroxenes) as a consequence of higher oxygen fugacity. The early and abundant crystallization of titanomagnetites as well as ferruginous and Ti-rich amphiboles disrupts the general balance of compositions toward a decreasing iron content $(\mathrm{FeO}$, first of all) in coexisting minerals, which may express itself in higher $\mathrm{Mg}$ numbers and in $\mathrm{FeO}-\mathrm{MnO}$ isomorphic replacement. This suggests that high $\mathrm{Mg}$ numbers and Mn content in olivines or pyroxenes may indicate the crystallization of minerals in a water-saturated and oxidizing environment. Similar conclusions were drawn from an analysis of conditions of pyroxene generation in acid volcanic rocks of the Uzon-Geyzer area of Kamchatka [Grib, 1997]. High oxygen fugacity and early crystallization of titanomagnetites may also be responsible for reverse zoning in the character of the $\mathrm{Fe}-\mathrm{Mg}$ ratio in silicates at lower temperatures [Martynov and Chubarov, 1982]. There is also some experimental evidence [Speidel and Nofriger, 1968] for rising $\mathrm{MgO}$ content in olivine in paragenesis with magnetite with increasing $f_{\mathrm{O}_{2}}$ and decreasing temperature.

On the basis of experimental data the concept was formed [Ringwood, 1975] that in the case of high water content in andesite magma melts, more calcic plagioclases crystallize compared with crystallization in anhydrous conditions. According to [Freely and Dungan, 1996; Panjasawatwong et al., 1995], the content of the anorthite component in plagioclase is determined by bulk-rock chemistry and water concentration in the melt. Therefore, the anomalous excess of the modal composition of plagioclase over the normative one (with moderate alkalinity and no evidence for melt mixing) may be interpreted as a high water-saturation of the melts. This discrepancy of plagioclase compositions may also disturb the total balance of the components, creating a deficit of $\mathrm{CaO}$ and $\mathrm{Al}_{2} \mathrm{O}_{3}$, but an excess of $\mathrm{SiO}_{2}$, and result in a situation in which coexisting olivines will be depleted in $\mathrm{CaO}$ and, jointly with low-calcium and low-aluminous clinopyroxenes, orthopyroxenes will crystallize. In combination with other known indicators (the presence of amphibole or traces of its dissociation), these features may also be used to judge the high water content in a magma melt.

\section{Conditions of the Formation of Rock Associations in the Massif}

Thus, the Kekuknai massif consists of five unevenaged rock associations. Their petrologic and geochemical characteristics are shown in Fig. 2 and major mineralogical features in Tables 1-4 and in Figs. 3-8 and 10. Here, we carry out their comparative analysis.

1. The island-arc (orogenic) (by geochemical characteristics) trachybasalt-trachydacite association of the shield-shaped volcano and extrusions (Fig. 2, field I) was formed in conditions of high oxidation potential 
and, probably, high water-saturation of melts, although amphibole in the form of sub-phenocrysts is noted only in some extrusive trachyandesites and trachydacites. Inclusions of titanomagnetites occur in the earliest generations of olivines and pyroxenes from the trachybasalts of the edifice accompanying all the stages of rock crystallization (Figs. 3, 4, 6). The overwhelming majority of titanomagnetites are noted for their high degree of iron oxidation and higher $\mathrm{MnO}$ and $\mathrm{TiO}_{2}$ contents (Fig. 3). Olivines and pyroxenes with anomalously high $\mathrm{Mg}$ numbers are found in more ferruginous (in bulkrock chemistry) trachybasalts (Figs. 4 and 6, as well as samples 141 and 144 compared to samples 136 and 161). In addition, most olivines are rich in $\mathrm{MnO}$ and its concentration rapidly increases with increasing iron content in the mineral. A peak of enrichment in this component is also noted in clinopyroxenes (Figs. 5a, 5b). Plagioclases in some trachybasalts (Fig. 8, samples 144,136 ) are very rich in the anorthite component, causing a deficit of $\mathrm{CaO}$ and this is expressed in lower alumina presence in clinopyroxenes of some microlites (Fig. 7a), low $\mathrm{CaO}$ in ferruginous olivines, and a wide occurrence of orthopyroxenes (Figs. 10a, $10 \mathrm{~b})$.

2. The intermediate in geochemical features trachybasalt association of the early stage of areal volcanism has a vertical $\mathrm{Nb}-\mathrm{K}$ ratio trend (Fig. 2, field II). The lower part of this trend (the neck trachybasalt, sample $\mathrm{k} 53 \mathrm{a}$ ) is very close to the trachybasalts of the pre-caldera edifice in composition and generation conditions, but volcanic rocks of the upper part of the trend (samples k57 and 4958 of the flow of Zarosshii cinder cone) are intermediate in composition between the trachybasalts of the edifice and areal hawaiites. Volatile components (including water) and high oxygen fugacity supposedly played a large role only in the formation of the neck trachybasalts (titanomagnetite control and $\mathrm{MnO}$ and $\mathrm{CaO}$ anomalies in olivines). For the rest of the trachybasalts one obviously had reducing conditions (control of chrome-aluminum spinel at low $\mathrm{MnO}$ contents in this mineral and in clinopyroxene, good Fo-MnO and $\mathrm{CaO}-\mathrm{Fo}$ correlations in olivine). The absence of amphibole and traces of its disintegration indicate the relative dryness of original melts. Rocks of the Zarosshii cone display an absence of melt fractionation: while the $\mathrm{Mg}$ number of olivine has an extremely wide range $\left(\mathrm{Fo}_{86-56}\right)$ in trachybasalts of the flow; the total composition of the cone rocks and of the flow from it are practically the same.

3. The intermediate in composition association of amphibole andesite-basalts of the cinder cones of the early stage of areal volcanism possesses a similar nearly vertical trend of the $\mathrm{Nb}-\mathrm{K}$ ratio (Fig. 2a, field III), which in its upper part seems to continue in the andesite-basalt compositions (samples k41 and 138) of the hawaiite-mugearite association (IV) with some shift in
$\mathrm{K}$, and in the lower part turns toward the field of the trachybasalt-trachydacite association. In composition, textural characteristics, and crystallization conditions, the andesite-basalts of both groups (association III and I) are similar: titanomagnetite control, presence of amphibole or structures of its disintegration, a high content of $\mathrm{MnO}$ in olivines and clinopyroxenes combined with similar $\mathrm{Mg}$ numbers at the same levels (Figs. 5a, 5c, 5b, 5d), a negative $\mathrm{CaO}$ anomaly in olivines (Figs. 10a, c) and high plagioclase basicity (Fig. 8, samples 147, 157). All this is evidence of high level of water saturation and oxidation conditions of the melts.

4. The hawaiite-mugearite (andesite-basalt) association of the middle stage of areal volcanism (intraplate in its geochemical features) was essentially formed from melts with high concentrations of melt- and fluidmobile components, which started to crystallize in conditions of spinel-olivine equilibrium at a low oxygen fugacity. In the course of melt evolution, the concentrations of some elements change substantially and the degree of water saturation and oxidation increases. Two rock series develop: (1) hawaiite-andesite-basalt and (2) hawaiite-mugearite.

The first one is characterized by a sub-vertical $\mathrm{Nb}-$ $\mathrm{K}$ decompression trend with low water content and low oxygen fugacity at the trend's beginning, but this takes place with increasing parameters at the transition to andesite-basalts (Fig. 2a, IV; Fig. 2b-2d) (hawaiites, samples 155, 2614, 49055, and 150; andesite-basalts, samples k47, k41, 148, 49064, 139, and 138) as the $\mathrm{Nb}$ concentration decreases and the silicic acidity of the rocks increases. Crystallization of melts of this association commenced under the control of high-alumina spinel and continued with a decreasing alumina content in this mineral $\left(\mathrm{Sp}_{\mathrm{Al}_{46-47}} \rightarrow \mathrm{Sp}_{\mathrm{Al}_{23-32}} \rightarrow \mathrm{Sp}_{\mathrm{Al}_{17}} \rightarrow\right.$ $\mathrm{Sp}_{\mathrm{Al}_{13-14}} \rightarrow \mathrm{Sp}_{\mathrm{Al}_{15}}$ ). Rocks of this group do not contain amphibole, except in shadow forms of hornblende disintegration in one of the necks (sample 155) and finds of small grains of this mineral (in aggregates with clinopyroxene and K-feldspar) in andesitebasalts (samples 49064, 138).

The hawaiite-mugearite series is characterized by a correlative $\mathrm{Nb}-\mathrm{K}$ ratio trend (Fig. 2a, field IV; Fig. 2bd, hawaiite, sample 49067, mugearites, samples 2751, $152-1,153,154)$ during increasing $N b$ concentration and rising $\mathrm{SiO}_{2}$ of rocks, pseudo-fractionation with high water presence and high oxygen fugacity from the first stages of rock crystallization. Rocks of this series are normally characterized by an early spinel-aluminum control with the presence of phenocrysts of amphibole in hawaiites and transition to titanomagnetite parageneses with amphibole in mugearites.

These two series are clearly discriminated by the $\mathrm{Mn}-\mathrm{Fo}$ ratio (Fig. 5e) and $\mathrm{CaO}-\mathrm{Fo}$ in olivines (Fig. 10e). In addition, clinopyroxenes from andesite- 


\begin{tabular}{|c|c|c|c|c|c|c|c|c|c|c|c|c|c|c|}
\hline \multirow{4}{*}{$\frac{\stackrel{\Xi}{ \pm}}{\frac{\Xi}{E}}$} & $\underset{\sigma}{i}$ & $\underline{\sqrt{ }}$ & $\stackrel{\sim}{\sim}$ & 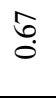 & $\begin{array}{l}\hat{\widetilde{\gamma}} \\
\tilde{f}\end{array}$ & $\stackrel{3}{r}$ & $\stackrel{n}{=}$ & $\stackrel{\vec{\oplus}}{\stackrel{\vartheta}{2}}$ & $\begin{array}{l}\text { ळे } \\
\dot{ \pm}\end{array}$ & oे. & $\frac{ \pm}{0}$ & 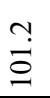 & $\begin{array}{l}n \\
\tilde{n} \\
\hat{n}\end{array}$ & $\underset{0}{*}$ \\
\hline & $\stackrel{\infty 00}{\Xi}$ & $\stackrel{2}{2}$ & $\tilde{\imath}$ & $\begin{array}{l}\stackrel{\circ}{n} \\
\stackrel{0}{0}\end{array}$ & $\hat{\hat{n}}$ & $\begin{array}{l}\dot{J} \\
\dot{J}\end{array}$ & 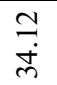 & $\hat{\imath}$ & $\begin{array}{l}\stackrel{\text { fn }}{+} \\
\stackrel{f}{*}\end{array}$ & กุ & 0 & $\begin{array}{l}\infty \\
\infty \\
\alpha\end{array}$ & $\stackrel{m}{\stackrel{\infty}{\infty}}$ & $\stackrel{\text { లి }}{\rightarrow}$ \\
\hline & \multirow{2}{*}{$=$} & \multirow{2}{*}{$\stackrel{+\infty}{+}$} & $\widetilde{\sim}$ & $\begin{array}{l}\tilde{\sigma} \\
\text { Q }\end{array}$ & $\begin{array}{l}\infty \\
\stackrel{\infty}{6}\end{array}$ & $\begin{array}{l}\vec{\sigma} \\
\ddot{i}\end{array}$ & 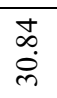 & $\begin{array}{l}\text { oे } \\
\text { ì }\end{array}$ & $\begin{array}{l}\infty \\
\dot{\infty} \\
i\end{array}$ & $\stackrel{m}{0}$ & 0 & $\hat{\ddot{\theta}}$ & $\stackrel{m}{n}$ & ڤ̊ \\
\hline & & & $\vec{\sim}$ & $\stackrel{\sim}{\longrightarrow}$ & $\begin{array}{l}\infty \\
\infty \\
\dot{m}\end{array}$ & $\begin{array}{l}\stackrel{2}{\circ} \\
\dot{\Xi}\end{array}$ & $\begin{array}{l}\stackrel{n}{n} \\
\stackrel{n}{n}\end{array}$ & 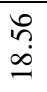 & $\begin{array}{l}\dot{D} \\
\infty \\
\dot{\omega}\end{array}$ & సุ. & $\frac{m}{0}$ & $\stackrel{m}{a}$ & 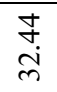 & $\stackrel{\varrho}{=}$ \\
\hline \multirow{8}{*}{ 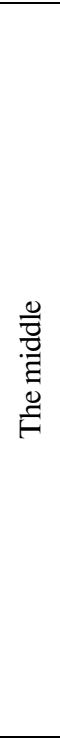 } & \multirow{4}{*}{ 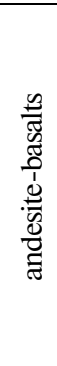 } & \multirow{2}{*}{ 舀 } & ఠి & $\stackrel{\sim}{\sim}$ & $\stackrel{\Xi}{\Xi}$ & 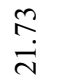 & $\begin{array}{l}\infty \\
\dot{0} \\
\ddot{d}\end{array}$ & $\begin{array}{l}\text { กิ } \\
\text { nิ }\end{array}$ & $\begin{array}{l}\infty \\
\infty \\
\emptyset\end{array}$ & $\stackrel{\infty}{0}$ & $\frac{6}{0}$ & $\hat{8}$ & $\begin{array}{l}\stackrel{n}{f} \\
\text { i } \\
\infty\end{array}$ & $\begin{array}{l}n \\
\infty \\
0\end{array}$ \\
\hline & & & 9 & $\tilde{n}$ & $\stackrel{ }{\Xi}$ & 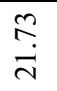 & $\begin{array}{l}\infty \\
\infty \\
\ddot{n}\end{array}$ & 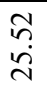 & $\begin{array}{l}\infty \\
\infty \\
\infty \\
b\end{array}$ & $\underset{0}{F}$ & $\begin{array}{l}0 \\
\div \\
0\end{array}$ & $\ddot{\dot{\theta}}$ & 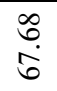 & $\begin{array}{l}\infty \\
\infty \\
0\end{array}$ \\
\hline & & $\stackrel{\infty}{=}$ & 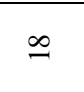 & $\begin{array}{l}\stackrel{8}{\circ} \\
\dot{+}\end{array}$ & $\begin{array}{l}\infty \\
\dot{0} \\
\dot{\Xi}\end{array}$ & $\begin{array}{l}\tilde{N} \\
\stackrel{\sim}{\omega} \\
\dot{\nu}\end{array}$ & $\overline{\text { aे }}$ & $\begin{array}{l}n \\
\stackrel{n}{d} \\
\vec{v}\end{array}$ & ๖ั & กี & 0 & $\begin{array}{l}\infty \\
\dot{8} \\
\varrho\end{array}$ & $\begin{array}{l}\stackrel{f}{f} \\
\infty \\
\infty\end{array}$ & $\stackrel{8}{8}$ \\
\hline & & $\stackrel{\infty}{ \pm}$ & $=$ & $\stackrel{\infty}{0}$ & $\underset{+}{\stackrel{F}{*}}$ & $\begin{array}{l}\hat{\hat{\sigma}} \\
\stackrel{\dot{q}}{ }\end{array}$ & $\begin{array}{l}\tilde{n} \\
\stackrel{n}{n}\end{array}$ & $\begin{array}{l}\vec{\partial} \\
\text { ij }\end{array}$ & $\stackrel{\odot}{-}$ & స్ & $\frac{0}{0}$ & $\begin{array}{l}\hat{\sigma} \\
\infty \\
\infty\end{array}$ & $\begin{array}{l}\vec{Ð} \\
\dot{\infty}\end{array}$ & $\stackrel{\infty}{\circ}$ \\
\hline & $\stackrel{\infty 00}{\Xi}$ & $\stackrel{+}{n}$ & $\stackrel{\bullet}{0}$ & $\stackrel{\Xi}{\Xi}$ & $\stackrel{n}{\hat{i}}$ & $\begin{array}{l}\hat{\infty} \\
\dot{J}\end{array}$ & $\overrightarrow{=}$ & 0 & $\stackrel{+}{n}$ & $\begin{array}{l}n \\
\ddot{0}\end{array}$ & 0 & $\stackrel{\infty}{\dot{8}}$ & $\begin{array}{l} \\
\text { m. } \\
\infty\end{array}$ & $\stackrel{\infty}{=}$ \\
\hline & 当 & $\begin{array}{l}\hat{\delta} \\
\dot{\sigma}\end{array}$ & $\cong$ & ڤे & $\begin{array}{l}n \\
\stackrel{0}{0} \\
\tilde{n}\end{array}$ & $\stackrel{\text { ڤ̆ }}{=}$ & 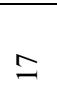 & $\begin{array}{l}\bar{\sigma} \\
\stackrel{0}{0}\end{array}$ & $\begin{array}{l}n \\
\infty \\
\end{array}$ & 0 & 0 & $\overrightarrow{8}$ & $\frac{\hat{n}}{n}$ & $\stackrel{R}{0}$ \\
\hline & 3 & $n$ & $\Xi$ & तु & $\stackrel{\widehat{\partial}}{\text { in }}$ & $\begin{array}{l}\infty \\
\ddot{n} \\
\ddot{n}\end{array}$ & $\stackrel{\hat{f}}{\dot{m}}$ & 0 & $\bar{a}$ & 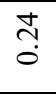 & $\stackrel{0}{0}$ & $\stackrel{a}{0}$ & 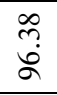 & $\underset{-}{8}$ \\
\hline & $=$ & $\underline{n}$ & $\underline{n}$ & ?ִ & 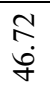 & $\stackrel{t}{t}$ & $\begin{array}{l}\bar{\infty} \\
\dot{\Xi}\end{array}$ & $\begin{array}{l}\vec{\sigma} \\
\dot{i}\end{array}$ & 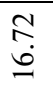 & $\frac{1}{3}$ & $\frac{n}{0}$ & $\begin{array}{l}\infty \\
\stackrel{8}{0}\end{array}$ & $\frac{\vec{m}}{m}$ & \begin{tabular}{l}
0 \\
\multirow{0}{0}{}
\end{tabular} \\
\hline & & $\tilde{\Omega}$ & $\simeq$ & $\begin{array}{l}\stackrel{g}{\mathrm{~d}} \\
\text { i }\end{array}$ & 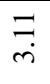 & $\begin{array}{l}\stackrel{f}{q} \\
\stackrel{g}{q}\end{array}$ & $\begin{array}{c}\hat{m} \\
\infty \\
\infty\end{array}$ & 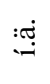 & $\stackrel{\infty}{i}$ & $\vec{\forall}$ & $\stackrel{\dot{\jmath}}{\dot{g}}$ & $\begin{array}{l}0 \\
\dot{8}\end{array}$ & $\begin{array}{l}\bar{n} \\
\infty \\
\infty\end{array}$ & $\stackrel{m}{=}$ \\
\hline हี & & $\infty$ & $=$ & $\begin{array}{l}\stackrel{\circ}{\infty} \\
\stackrel{+}{+}\end{array}$ & $\begin{array}{l}\stackrel{+}{m} \\
\dot{\Xi}\end{array}$ & 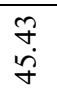 & $\stackrel{\substack{n \\
m}}{m}$ & 0 & $\begin{array}{l}\hat{\sigma} \\
\dot{+}\end{array}$ & $\stackrel{m}{0}$ & 0 & ষ্் & 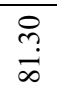 & $\underset{J}{J}$ \\
\hline$\frac{\frac{\pi}{0}}{\frac{\pi}{\pi}}$ & 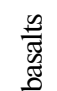 & পे & 으 & $\begin{array}{l}0 \\
=\end{array}$ & $\vec{\nabla}$ & $\stackrel{n}{\simeq}$ & $\begin{array}{l}0 \\
\underset{d}{i} \\
\text { d }\end{array}$ & $\begin{array}{l}\text { î } \\
\text { ¿े }\end{array}$ & oे & ָे & $\stackrel{0}{\circ}$ & $\begin{array}{l}\text { तิ } \\
\text { ลे }\end{array}$ & $\begin{array}{l}\vec{t} \\
\dot{b} \\
\dot{q}\end{array}$ & $\begin{array}{l}n \\
\stackrel{2}{0}\end{array}$ \\
\hline $\begin{array}{l}\frac{\tilde{a}}{\pi} \\
\stackrel{\vec{\pi}}{\bar{E}}\end{array}$ & $\begin{array}{l}\overrightarrow{0} \\
\text { हूँ }\end{array}$ & & $a$ & $\begin{array}{l}\infty \\
\infty \\
\infty\end{array}$ & $\stackrel{n}{n}$ & $\begin{array}{l}\bar{\sigma} \\
\vec{\gamma}\end{array}$ & $\begin{array}{l}\dot{J} \\
\infty \\
\infty \\
m\end{array}$ & $\hat{\circ}$ & $\hat{n}$ & 0 & 0 & $\begin{array}{l}\infty \\
\stackrel{2}{n} \\
\alpha\end{array}$ & $\begin{array}{l}\vec{b} \\
\stackrel{a}{a}\end{array}$ & $\stackrel{\stackrel{J}{I}}{-}$ \\
\hline$\underset{\tilde{E}}{\dot{E}}$ & & $\hat{\tilde{\theta}}$ & $\infty$ & $\stackrel{ }{I}$ & $\vec{\infty}$ & $\begin{array}{l}\infty \\
\infty \\
\ddot{n}\end{array}$ & 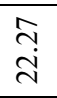 & $\begin{array}{l}\stackrel{i}{\hat{i}} \\
\text { m }\end{array}$ & $\begin{array}{l}\hat{\infty} \\
\infty \\
\infty\end{array}$ & $\begin{array}{l}\text { ָ̦ } \\
\text { o }\end{array}$ & $\stackrel{t}{0}$ & $\begin{array}{l}\infty \\
\infty \\
\alpha\end{array}$ & $\begin{array}{l}\infty \\
\stackrel{\infty}{0} \\
\infty \\
i\end{array}$ & $\overrightarrow{\hat{0}}$ \\
\hline & & & $n$ & $\stackrel{2}{\circ}$ & 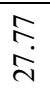 & $\begin{array}{l}\overrightarrow{7} \\
\infty\end{array}$ & $\begin{array}{l}\vec{a} \\
\stackrel{\vec{\sim}}{\mathbf{v}}\end{array}$ & $\frac{\hat{\sigma}}{\dot{m}}$ & $\begin{array}{l}\ddot{0} \\
\dot{0}\end{array}$ & กิ & $\stackrel{\ddot{g}}{\ddot{g}}$ & $\overrightarrow{8}$ & $\begin{array}{l}+ \\
\infty \\
\ddot{b}\end{array}$ & ले \\
\hline & స్ & 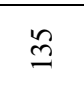 & 0 & $\stackrel{\tilde{\sigma}}{\tilde{\varrho}}$ & $\stackrel{\Im}{\leftrightarrows}$ & $\begin{array}{l}\frac{n}{a} \\
\frac{a}{q}\end{array}$ & $\underset{\substack{+\infty}}{\substack{\infty \\
m}}$ & 0 & $\stackrel{n}{\mathfrak{r}}$ & $\stackrel{\infty}{\circ}$ & 0 & $\stackrel{1}{a}$ & $\begin{array}{l}\infty \\
m \\
\\
\alpha\end{array}$ & $\widehat{\widehat{N}}$ \\
\hline & & $\bar{\sigma}$ & in & 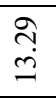 & $\stackrel{\sim}{\sim}$ & $\stackrel{\bar{z}}{\bar{z}}$ & $\begin{array}{l}\hat{0} \\
\text { ले }\end{array}$ & 0 & $\stackrel{+}{i}$ & $\tilde{n}$ & 0 & $\begin{array}{l}\hat{b} \\
\infty \\
\infty\end{array}$ & $\frac{7}{8}$ & $\stackrel{n}{\varrho}$ \\
\hline$\frac{\pi}{0}$ & & $=$ & $\nabla$ & $\vec{a}$ & $\stackrel{+}{+}$ & 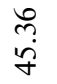 & $\underset{m}{\infty}$ & 0 & $\stackrel{\infty}{-}$ & $\stackrel{\mathfrak{H}}{\circ}$ & 0 & $\vec{a}$ & $\hat{a}$ & 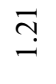 \\
\hline ڤ̇ & $\sum_{0}^{0}$ & $\stackrel{\cong}{\cong}$ & $m$ & $\stackrel{\sim}{\sim}$ & $\stackrel{n}{n}$ & $\begin{array}{l}\dot{0} \\
\text { ஜें }\end{array}$ & $\overline{\bar{a}}$ & $\bar{n}$ & $\stackrel{n}{n}$ & ?ె. & 0 & $\ddot{8}$ & $\begin{array}{l}\infty \\
\stackrel{\circ}{\alpha} \\
\alpha\end{array}$ & $\begin{array}{l}\infty \\
\stackrel{\infty}{\infty} \\
\end{array}$ \\
\hline & & $\Varangle$ & $\sim$ & $\frac{T}{i n}$ & $\stackrel{2}{0}$ & $\underset{\substack{n \\
i n}}{i}$ & $\begin{array}{l}\infty \\
\dot{m}\end{array}$ & 0 & 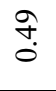 & $\hat{n}$ & 0 & $\begin{array}{l}\infty \\
\stackrel{\infty}{\alpha}\end{array}$ & 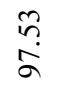 & $\underset{\sigma}{\mathbb{\sigma}}$ \\
\hline & & I & - & 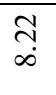 & $\begin{array}{l}n \\
i n \\
i\end{array}$ & $\underset{i}{\stackrel{i}{i}}$ & $\begin{array}{l}\stackrel{+}{+} \\
\text { f. }\end{array}$ & $\bar{\circ}$ & $\begin{array}{l}\hat{\infty} \\
\stackrel{i}{i}\end{array}$ & 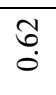 & 0 & $\stackrel{n}{0}$ & 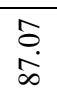 & $\stackrel{n}{n}$ \\
\hline $\begin{array}{l}\text { 总 } \\
\text { 吾 }\end{array}$ & $\begin{array}{l}\frac{u}{8} \\
\simeq\end{array}$ & 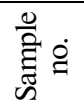 & $\overline{\frac{\pi}{5}} \dot{g}$ & $\stackrel{N}{\varrho}$ & 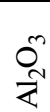 & $\overbrace{}^{m}$ & O & Оో & $\stackrel{\circ}{\sum_{\Sigma}^{\infty}}$ & $\stackrel{O}{\Xi}$ & $\stackrel{\circ}{\gtrless}$ & ڤ్ & $\sum_{I}$ & $0^{m}$ \\
\hline
\end{tabular}




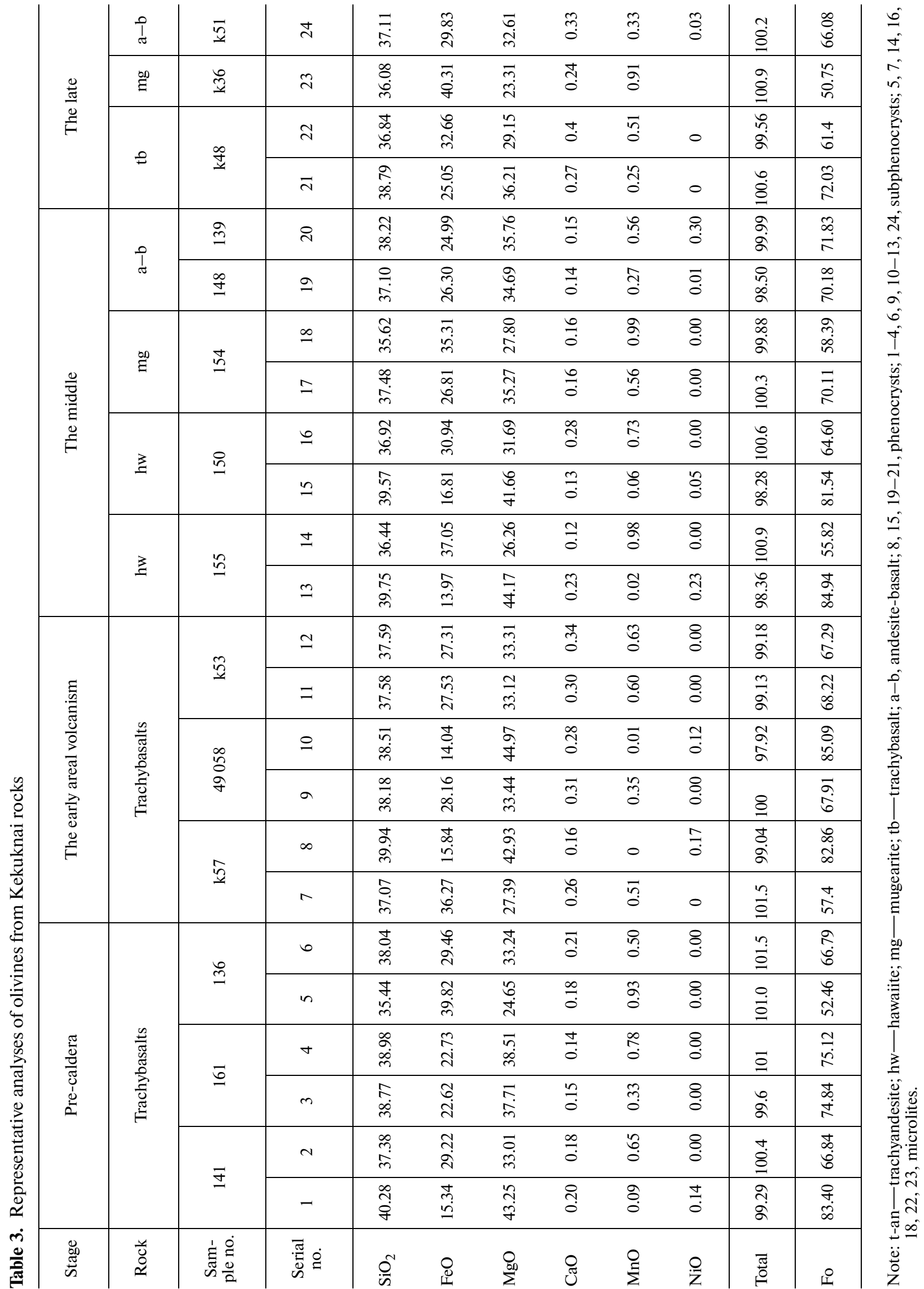




\begin{tabular}{|c|c|c|c|c|c|c|c|c|c|c|c|c|c|c|c|}
\hline \multirow{4}{*}{$\begin{array}{l}\frac{0}{\pi} \\
\frac{\pi}{E}\end{array}$} & $\underset{\sigma}{1}$ & $\overline{\underline{a}}$ & $\stackrel{\sim}{\sim}$ & 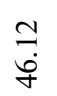 & $\stackrel{\vec{i}}{\vec{i}}$ & $\stackrel{\infty}{\stackrel{\circ}{\longrightarrow}}$ & $\stackrel{\stackrel{g}{\circ}}{\stackrel{\theta}{0}}$ & $\stackrel{8}{0}$ & $\begin{array}{l}\hat{\leftrightarrow} \\
\stackrel{g}{\rightarrow}\end{array}$ & 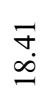 & 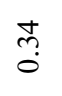 & $\stackrel{\Delta}{0}$ & $\stackrel{\tilde{o}}{0}$ & $\begin{array}{l}0 \\
0 \\
\infty\end{array}$ & $\begin{array}{l}\infty \\
\stackrel{\sim}{\Lambda} \\
\stackrel{n}{n}\end{array}$ \\
\hline & $\stackrel{\infty 00}{E}$ & $\underset{\mathscr{q}}{\mathscr{q}}$ & $\widetilde{\lambda}$ & $\begin{array}{l}\text { na } \\
\text { ó }\end{array}$ & $\stackrel{\infty}{\stackrel{\infty}{ت}}$ & 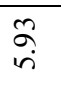 & ָָ & $\stackrel{8}{0}$ & $\underset{\widetilde{N}}{\tilde{I}}$ & $\begin{array}{l}\stackrel{9}{\vec{\lambda}} \\
\stackrel{\mathrm{d}}{ }\end{array}$ & $\stackrel{R}{R}$ & $\stackrel{\tilde{O}}{\circ}$ & $\stackrel{\leftrightarrow}{0}$ & $\vec{a}$ & $\begin{array}{l}\text { in } \\
\text { ì }\end{array}$ \\
\hline & \multirow{2}{*}{ 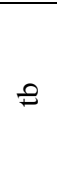 } & \multirow{2}{*}{$\stackrel{\infty}{+\infty}$} & $\pi$ & $\begin{array}{l}\text { 迎 } \\
\text { of }\end{array}$ & 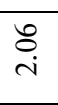 & $\stackrel{\tilde{n}}{\dot{\sigma}}$ & $\begin{array}{c}\infty \\
\infty \\
\infty \\
\infty\end{array}$ & $\stackrel{8}{0}$ & 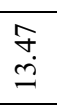 & $\underset{\dot{H}}{\vec{H}}$ & $\stackrel{n}{o}$ & $\stackrel{\circ}{\circ}$ & $\stackrel{8}{\circ}$ & $a_{\alpha}^{a}$ & 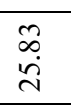 \\
\hline & & & $\bar{\sim}$ & $\begin{array}{l}\hat{\sigma} \\
\dot{a}\end{array}$ & in & $\stackrel{\leftrightarrow}{i}$ & $\begin{array}{l}\text { ते } \\
\infty\end{array}$ & $\stackrel{8}{0}$ & $\stackrel{\tilde{\dot{m}}}{\hat{m}}$ & 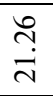 & $\stackrel{ \pm}{=}$ & 菅 & $\stackrel{8}{\circ}$ & น̆ & $\begin{array}{l}\stackrel{\infty}{\stackrel{\leftrightarrow}{d}} \\
\text { a }\end{array}$ \\
\hline \multirow{7}{*}{ 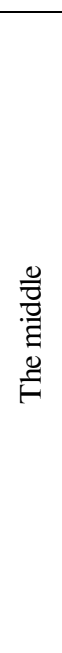 } & \multirow{3}{*}{ 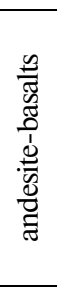 } & $\hat{\mathrm{m}}$ & ते & $\begin{array}{l}\text { f. } \\
\text { gे }\end{array}$ & 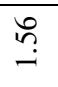 & $\widehat{\widetilde{i}}$ & $\begin{array}{c}\tilde{3} \\
\stackrel{2}{a}\end{array}$ & $\stackrel{े}{0}$ & 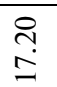 & $\underset{\tilde{g}}{\tilde{g}}$ & $\vec{i}$ & $\stackrel{d}{0}$ & if & 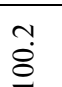 & $\underset{\tilde{m}}{\tilde{m}}$ \\
\hline & & $\stackrel{\infty}{\dddot{\infty}}$ & 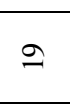 & 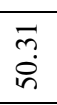 & $\stackrel{0}{\tilde{O}}$ & $\bar{F}$ & $\stackrel{8}{\circ}$ & $\tilde{\tilde{a}}$ & 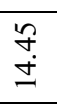 & $\stackrel{n}{n}$ & $\stackrel{\grave{o}}{0}$ & $\stackrel{8}{0}$ & $\stackrel{8}{0}$ & $\stackrel{b}{\infty}$ & 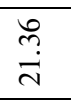 \\
\hline & & $\stackrel{\infty}{\underline{I}}$ & $\stackrel{\infty}{\sim}$ & $\stackrel{n}{\dot{n}}$ & $\stackrel{m}{=}$ & $\stackrel{\vec{\ominus}}{\stackrel{.}{0}}$ & Ș & $\stackrel{8}{0}$ & बें & 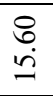 & $\stackrel{\infty}{\stackrel{i}{i}}$ & $\hat{n}$ & $\stackrel{8}{\circ}$ & $\begin{array}{l}\infty \\
\infty \\
\infty\end{array}$ & $\frac{n}{a}$ \\
\hline & $\stackrel{\infty 0}{g}$ & 壳 & 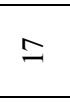 & 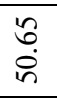 & $\begin{array}{l}\vec{\sigma} \\
0\end{array}$ & $\begin{array}{l}\stackrel{\wp}{\sim} \\
\stackrel{2}{*}\end{array}$ & $\dot{a}$ & $\stackrel{8}{\circ}$ & 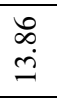 & 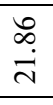 & ô & $\overrightarrow{0}$. & 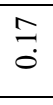 & $\overline{\dot{\Xi}}$ & 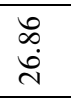 \\
\hline & 录 & $\stackrel{8}{n}$ & $\underline{\varrho}$ & $\begin{array}{l}\hat{n} \\
\hat{a}\end{array}$ & $\stackrel{\Xi}{\leftrightarrows}$ & $\underset{f}{\vec{f}}$ & $\underset{\infty}{+}$ & $\stackrel{8}{\circ}$ & $\begin{array}{l}\overrightarrow{\overrightarrow{+}} \\
\dot{I}\end{array}$ & $\stackrel{\text { }}{\stackrel{\partial}{\partial}}$ & n̊. & $\tilde{O}$ & $\overline{0}$ & $\begin{array}{l}n \\
\infty \\
\infty\end{array}$ & $\begin{array}{l}\infty \\
\infty \\
\tilde{\sim}\end{array}$ \\
\hline & & & $\stackrel{n}{2}$ & 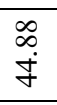 & 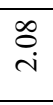 & 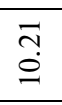 & 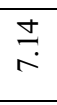 & $\stackrel{8}{\circ}$ & 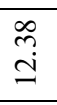 & 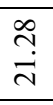 & $\stackrel{\infty}{0}$ & $\stackrel{\overbrace{}}{0}$ & $\stackrel{8}{0}$ & $\begin{array}{l}\stackrel{\infty}{\infty} \\
\stackrel{\infty}{\circ}\end{array}$ & $\begin{array}{l}\text { 导 } \\
\text { d }\end{array}$ \\
\hline & 昼 & $\stackrel{n}{n}$ & \pm & 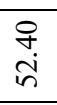 & तิ & $\underset{i}{i}$ & 脬 & $\tilde{O}$ & $\begin{array}{l}\stackrel{n}{n} \\
\dot{n}\end{array}$ & 劲 & $\hat{0}$ & $\overrightarrow{0}$ & $\overline{0}$ & aे & $\begin{array}{l}\tilde{\delta} \\
\stackrel{\sigma}{0}\end{array}$ \\
\hline \multirow{6}{*}{ 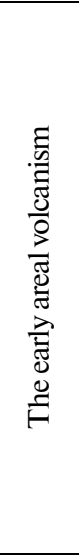 } & $\underset{d}{i}$ & in & 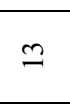 & $\begin{array}{l}\ddot{n} \\
\dot{q}\end{array}$ & $\stackrel{\text { I }}{\text { I }}$ & $\begin{array}{l}\widehat{\mathrm{I}} \\
\mathrm{I}\end{array}$ & $\tilde{\Omega}$ & $\stackrel{8}{0}$ & 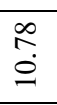 & $\underset{\vec{i}}{\bar{i}}$ & $\stackrel{m}{0}$ & $\stackrel{8}{8}$ & $\stackrel{8}{\circ}$ & $\stackrel{\partial}{\alpha}$ & $\stackrel{\stackrel{n}{b}}{m}$ \\
\hline & \multirow{5}{*}{ 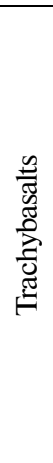 } & \multirow{2}{*}{$\tilde{\hat{\sigma}}$} & $\simeq$ & $\begin{array}{l}\text { के } \\
\text { ְु }\end{array}$ & 㐫 & $\underset{\infty}{f}$ & $\stackrel{\circ}{\circ}$ & $\stackrel{8}{\circ}$ & $\vec{m}$ & $\begin{array}{l}\text { त् } \\
\text { İ }\end{array}$ & oे & $\overline{0}$ & $\stackrel{8}{\circ}$ & ㅇ. & $\begin{array}{l}\text { oे } \\
\stackrel{\sim}{\Delta}\end{array}$ \\
\hline & & & $=$ & $\begin{array}{l}\stackrel{m}{\vec{i}} \\
\text { n. }\end{array}$ & ô & 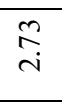 & $\begin{array}{l}\tilde{\infty} \\
\infty\end{array}$ & $\stackrel{8}{0}$ & 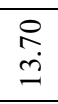 & $\begin{array}{l}\text { ते } \\
\text { ते }\end{array}$ & $\stackrel{\infty}{0}$ & $\stackrel{0}{0}$ & $\overline{0}$ & $\begin{array}{l}\infty \\
\stackrel{8}{\dot{g}}\end{array}$ & $\begin{array}{l}\infty \\
\stackrel{\infty}{\underline{n}}\end{array}$ \\
\hline & & \multirow{2}{*}{$\begin{array}{l}\underbrace{\infty}_{0} \\
\text { ò }\end{array}$} & 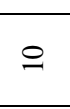 & $\begin{array}{l}\substack{\infty \\
\text { oj } \\
\dot{\sigma}} \\
\end{array}$ & $\stackrel{\overbrace{}}{\circ}$ & $\vec{b}$ & $\stackrel{?}{\stackrel{f}{r}}$ & $\stackrel{0}{0}$ & $\begin{array}{l}\stackrel{q}{q} \\
\stackrel{g}{2}\end{array}$ & $\stackrel{\vec{m}}{\vec{n}}$ & $\stackrel{ \pm}{ \pm}$ & $\overline{\tilde{s}}$ & d: & $\stackrel{\dot{\alpha}}{\circ}$ & $\stackrel{\hat{i}}{i}$ \\
\hline & & & $a$ & 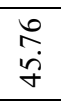 & : & $\stackrel{\Xi}{\Xi}$ & $\begin{array}{l}\hat{\sigma} \\
\dot{f}\end{array}$ & $\stackrel{8}{0}$ & $\begin{array}{l}\tilde{J} \\
\underline{\Xi}\end{array}$ & $\stackrel{\text { ते }}{\vec{N}}$ & 市 & तิ & $\stackrel{8}{0}$ & $\stackrel{+}{\circ}$ & $\begin{array}{l}\stackrel{t}{\Delta} \\
\stackrel{\Delta}{6} \\
\end{array}$ \\
\hline & & 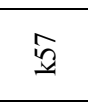 & $\infty$ & 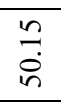 & $\bar{n}$ & $\stackrel{\infty}{\stackrel{\sim}{\sim}}$ & $\stackrel{\alpha}{\alpha}$ & $\bar{J}$ & 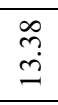 & $\begin{array}{l}\bar{\Delta} \\
\dot{\pi}\end{array}$ & 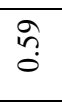 & $\overrightarrow{\dot{0}}$ & 8 & $\begin{array}{l}\infty \\
\alpha \\
\alpha\end{array}$ & $\frac{\infty}{a}$ \\
\hline \multirow{7}{*}{ 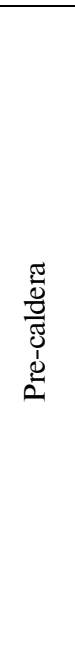 } & $\nsubseteq$ & 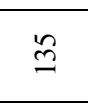 & $r$ & 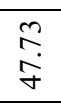 & $\stackrel{\text { Iิ }}{\mathrm{I}}$ & Fै & $\stackrel{\vec{S}}{\stackrel{S}{S}}$ & $\stackrel{0}{0}$ & 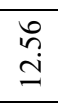 & 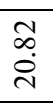 & 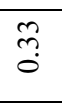 & $\stackrel{\leftrightarrow}{\circ}$ & i্ & $\underset{\dot{\alpha}}{\stackrel{\circ}{\circ}}$ & $\frac{\vec{m}}{m}$ \\
\hline & \multirow{6}{*}{ 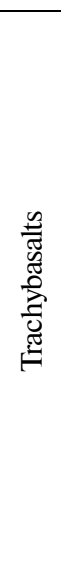 } & \multirow{3}{*}{$\underset{\Xi}{ }$} & 0 & $\begin{array}{l}\text { fे } \\
\dot{\sigma}\end{array}$ & $\stackrel{\circ}{\circ}$ & $\stackrel{m}{\vec{f}}$ & $\stackrel{\sim}{\stackrel{m}{\varrho}}$ & $\stackrel{8}{\circ}$ & 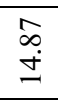 & 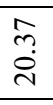 & 守 & 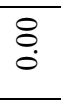 & $\stackrel{g}{0}$ & $\hat{\stackrel{\theta}{g}}$ & $\begin{array}{l}\text { oे } \\
\text { d. }\end{array}$ \\
\hline & & & $n$ & 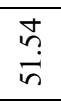 & in & $\widehat{\hat{n}}$ & ळ. & $\stackrel{8}{0}$ & $\stackrel{ }{\stackrel{I}{0}}$ & for & $\hat{\widehat{c}}$ & $\stackrel{8}{0}$ & $\stackrel{g}{0}$ & $\begin{array}{l}\infty \\
\stackrel{8}{0}\end{array}$ & $\begin{array}{l}\tilde{n} \\
\stackrel{d}{d}\end{array}$ \\
\hline & & & $\sigma$ & $\begin{array}{l}\hat{b} \\
\dot{+}\end{array}$ & $\stackrel{9}{\rightrightarrows}$ & 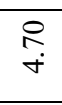 & $\stackrel{\leftrightarrow}{\stackrel{S}{0}}$ & $\stackrel{8}{\circ}$ & $\stackrel{f}{\underline{g}}$ & 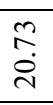 & $\hat{n}$ & $\stackrel{8}{0}$ & $\stackrel{\circ}{\circ}$ & $\stackrel{a}{\alpha}$ & $\begin{array}{l}5 \\
\dot{m} \\
\text { no }\end{array}$ \\
\hline & & $\stackrel{\overbrace{}}{0}$ & $m$ & 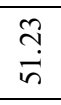 & S. & $\overline{\vec{i}}$ & तु & $\stackrel{8}{0}$ & 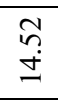 & $\stackrel{\overrightarrow{\dot{d}}}{\vec{d}}$ & 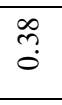 & $\tilde{O}$ & $\stackrel{ \pm}{\circ}$ & $\stackrel{\circ}{\circ}$ & 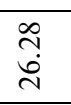 \\
\hline & & \multirow{2}{*}{ 寻 } & $\sim$ & 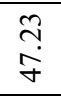 & 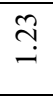 & $\stackrel{7}{\stackrel{2}{7}}$ & $\underset{\text { 帝 }}{\text {. }}$ & $\cong$ & $\stackrel{\text { I }}{\text { In }}$ & $\begin{array}{l}\tilde{\tilde{d}} \\
\text { d. }\end{array}$ & $\stackrel{m}{\hat{b}}$ & $\stackrel{\rho}{0}$ & 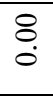 & $\begin{array}{l}3 \\
\infty \\
\infty\end{array}$ & $\overrightarrow{\vec{d}}$ \\
\hline & & & - & 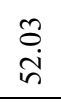 & $\stackrel{f}{o}$ & $\stackrel{n}{\hat{i}}$ & $\stackrel{\infty}{\infty}$ & $\stackrel{8}{0}$ & $\begin{array}{l}\stackrel{0}{2} \\
\stackrel{2}{n}\end{array}$ & 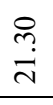 & $\begin{array}{l}\text { for } \\
0\end{array}$ & $\stackrel{8}{0}$ & $\stackrel{n}{0}$ & $\stackrel{\stackrel{\dot{\Xi}}{\Xi}}{ }$ & $\begin{array}{l}\stackrel{+}{\vec{*}} \\
\vec{\sim}\end{array}$ \\
\hline 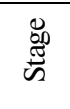 & 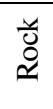 & 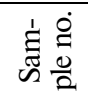 & 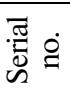 & $\overbrace{}^{N}$ & $\stackrel{\curvearrowright}{\mathscr{N}}$ & 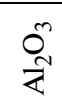 & \& & 今ో & $\stackrel{\circ}{\frac{o n}{2}}$ & \& & $\begin{array}{l}\text { Oे } \\
\text { בू }\end{array}$ & $\stackrel{0}{\widetilde{\beth}}$ & $\stackrel{\circ}{\Sigma}$ & 傿 & 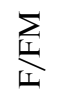 \\
\hline
\end{tabular}




\begin{tabular}{|c|c|c|c|c|c|c|c|c|c|c|c|c|c|c|}
\hline \multirow{4}{*}{$\begin{array}{l}\frac{\mathbb{J}}{g} \\
\stackrel{\Xi}{F}\end{array}$} & i & $\bar{\nabla}$ & $\stackrel{J}{\sim}$ & i & $\hat{m}$ & $\stackrel{+}{\circ}$ & $\overrightarrow{0}$ & $\begin{array}{l}\stackrel{0}{i} \\
\ddot{n}\end{array}$ & $\stackrel{\sim}{\sim}$ & $\overrightarrow{0}$ & $\hat{\sigma}$ & $\stackrel{\circ}{\circ}$ & $\tilde{\sigma}$ & $\stackrel{\infty}{\circ}$ \\
\hline & $\stackrel{\infty 00}{\Xi}$ & 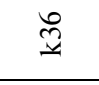 & $\ddot{\sim}$ & $\begin{array}{c}0 \\
\text { in }\end{array}$ & 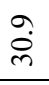 & $\hat{0}$ & $\stackrel{\circ}{\circ}$ & $\stackrel{\sim}{\ddot{2}}$ & $\underset{\dot{r}}{\dot{r}}$ & $\stackrel{+}{0}$ & $\Xi$ & $\stackrel{\circ}{\circ}$ & $\stackrel{?}{0}$ & $\hat{0}$ \\
\hline & \multirow{2}{*}{$=$} & \multirow{2}{*}{$\stackrel{\infty}{\stackrel{\infty}{ \pm}}$} & $\approx$ & ஜீ. & $\hat{\sigma}$ & $\stackrel{+}{0}$ & $\stackrel{\circ}{\circ}$ & $\tilde{o}$ & $\stackrel{\circ}{+}$ & $\stackrel{?}{0}$ & $\Xi$ & $\stackrel{0}{\circ}$ & $\stackrel{+}{\circ}$ & $\stackrel{\circ}{\circ}$ \\
\hline & & & $\vec{\sim}$ & $\hat{i}$ & $\frac{\nabla}{\dot{m}}$ & $\stackrel{0}{\circ}$ & $\stackrel{\circ}{\circ}$ & $\stackrel{\vec{\vartheta}}{\vec{g}}$ & $n$ & ? & 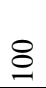 & $\stackrel{0}{0}$ & ? & $\tilde{o}$ \\
\hline \multirow{7}{*}{ 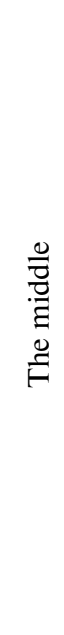 } & \multirow{3}{*}{ 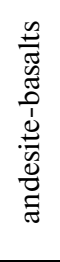 } & 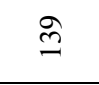 & $\stackrel{\sim}{~}$ & $\stackrel{n}{q}$ & $\stackrel{m}{\grave{n}}$ & $\dot{o}$ & $\overrightarrow{0}$ & $\hat{m}$ & $\stackrel{\circ}{+}$ & $\stackrel{m}{0}$ & $\hat{\alpha}$ & $\stackrel{+}{-}$ & $\overline{\dot{m}}$ & $\stackrel{+}{\stackrel{+}{0}}$ \\
\hline & & $\stackrel{\infty}{=}$ & 2 & $\begin{array}{l}\dot{0} \\
\dot{f}\end{array}$ & $\stackrel{+}{\dot{m}}$ & $\stackrel{+}{0}$ & $\stackrel{\circ}{\circ}$ & $\hat{\sigma}$ & 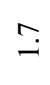 & $\overrightarrow{0}$ & $\stackrel{\circ}{\infty}$ & $\hat{0}$ & $\stackrel{\vec{n}}{\ddot{n}}$ & ले \\
\hline & & $\stackrel{\infty}{ \pm}$ & $\cong$ & $\stackrel{0}{\bar{n}}$ & ?ִ & 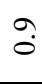 & $\overrightarrow{0}$ & 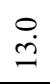 & $\stackrel{\varphi}{r}$ & m? & $\frac{m}{2}$ & $\dddot{r}$ & î & in \\
\hline & $\stackrel{\infty 00}{\Xi}$ & 苞 & $=$ & ஸֶ. & ले & $\hat{\sigma}$ & $\overrightarrow{0}$ & $\stackrel{\simeq}{\beth}$ & $\stackrel{m}{i}$ & ơ & $\overline{0}$ & $\dot{0}$ & $\stackrel{\sim}{2}$ & $\begin{array}{l}\infty \\
\stackrel{0}{\Omega}\end{array}$ \\
\hline & 胥 & $\stackrel{n}{n}$ & $\varrho$ & $\underset{\infty}{\stackrel{\sigma}{\sigma}}$ & $\vec{m}$ & $\stackrel{\circ}{\circ}$ & $\overrightarrow{0}$ & $\stackrel{0}{\circ}$ & $\stackrel{m}{i}$ & $\stackrel{\sim}{0}$ & 8 & $\stackrel{\circ}{-}$ & $\overrightarrow{\dot{\Omega}}$ & $\stackrel{\infty}{\infty}$ \\
\hline & 3 & $n$ & 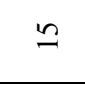 & 7 & $\ddot{a}$ & $\overline{0}$ & $\stackrel{\circ}{0}$ & $\tilde{0}$ & $\stackrel{m}{m}$ & $\stackrel{\circ}{\mathrm{I}}$ & $\cong$ & $\stackrel{\infty}{0}$ & $\begin{array}{l}\infty \\
\infty \\
\infty\end{array}$ & $\stackrel{\ominus}{-}$ \\
\hline & & & \pm & $\begin{array}{l}n \\
\ddot{n}\end{array}$ & $\begin{array}{l}\infty \\
\dot{m} \\
\dot{m}\end{array}$ & $\stackrel{n}{0}$ & $\overrightarrow{0}$ & $\dot{\vec{g}}$ & $\stackrel{\sim}{\sim}$ & $\stackrel{\circ}{\circ}$ & $\begin{array}{l}\infty \\
\infty \\
\infty\end{array}$ & $\stackrel{\circ}{\circ}$ & $\stackrel{\ddot{\lambda}}{\grave{\lambda}}$ & : \\
\hline & $i_{\sigma}^{0}$ & $\hat{n}$ & 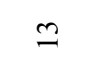 & $\begin{array}{l}\ddot{v} \\
\ddot{f}\end{array}$ & î & $\ddot{0}$ & $\stackrel{\circ}{\circ}$ & 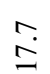 & $\stackrel{\sim}{\longrightarrow}$ & $\stackrel{0}{0}$ & 8 & $\stackrel{0}{0}$ & $\stackrel{n}{\varrho}$ & $\stackrel{\infty}{\infty}$ \\
\hline E్ & & $n$ & $\simeq$ & $\stackrel{\substack{n \\
\infty}}{\infty}$ & $\ddot{n}$ & $\stackrel{\infty}{0}$ & $\stackrel{\circ}{\circ}$ & $\stackrel{0}{r}$ & $\stackrel{\forall}{\dot{n}}$ & $\dot{o}$ & $\stackrel{n}{\infty}$ & $\stackrel{\infty}{+}$ & ث̊․․ & 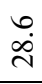 \\
\hline $\begin{array}{l}\frac{0}{0} \\
\frac{0}{\sigma}\end{array}$ & & 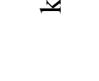 & $=$ & ఫे & $\vec{m}$ & $\hat{o}$ & $\stackrel{\circ}{\circ}$ & 吕 & $\stackrel{\circ}{i}$ & $\overrightarrow{0}$ & 8 & $\dot{0}$ & $\begin{array}{l}\circ \\
\stackrel{\infty}{\sim}\end{array}$ & 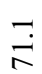 \\
\hline 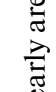 & $\frac{\tilde{D}}{\vec{\lambda}}$ & $\begin{array}{l}\infty \\
\stackrel{2}{a} \\
\stackrel{a}{q}\end{array}$ & 인 & $\begin{array}{l}\ddot{y} \\
\dot{f}\end{array}$ & $\ddot{n}$ & $\hat{o}$ & $\overrightarrow{0}$ & $\begin{array}{l}\infty \\
\infty \\
\infty\end{array}$ & $\stackrel{0}{0}$ & กั & $\stackrel{m}{\circ}$ & $\hat{o}$ & $\stackrel{\infty}{i n}$ & $\stackrel{m}{\alpha}$ \\
\hline$\stackrel{\mathscr{E}}{F}$ & & & $a$ & $\begin{array}{l}0 \\
\dot{b}\end{array}$ & $\stackrel{\sim}{\infty}$ & $\stackrel{?}{-}$ & $\stackrel{m}{0}$ & $\stackrel{\infty}{\circ}$ & $\ddot{n}$ & $\stackrel{\infty}{\varrho}$ & 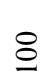 & تt & $\frac{9}{m}$ & $\dot{\check{m}}$ \\
\hline & & & $\infty$ & $\stackrel{m}{q}$ & $\underset{\text { ì }}{\stackrel{\nabla}{ }}$ & $\stackrel{\circ}{\circ}$ & $\overrightarrow{0}$ & $\begin{array}{l}n \\
n\end{array}$ & $\ddot{n}$ & $\overrightarrow{0}$ & $\Xi$ & $\hat{\sigma}$ & $\stackrel{\stackrel{\sim}{d}}{\text { d }}$ & ఠેे \\
\hline & $\underset{\stackrel{\varpi}{ \pm}}{\tilde{I}}$ & $\stackrel{n}{m}$ & $r$ & $\vec{n}$ & 官 & $\ddot{0}$ & $\stackrel{0}{\circ}$ & $\stackrel{\sim}{\ddot{n}}$ & $\stackrel{\dot{r}}{\dot{r}}$ & $\stackrel{\text { ọ }}{0}$ & ホั. & $\stackrel{m}{\rightarrow}$ & $\vec{m}$ & $\begin{array}{l}\stackrel{0}{0} \\
\stackrel{0}{6}\end{array}$ \\
\hline & & & 0 & $\stackrel{\stackrel{N}{\sim}}{\stackrel{N}{n}}$ & $\underset{\sim}{\stackrel{\sim}{\sim}}$ & $\stackrel{\infty}{\circ}$ & $\overrightarrow{0}$ & $\overrightarrow{0}$ & $\begin{array}{r}\dot{r} \\
\dot{0}\end{array}$ & $\stackrel{0}{\circ}$ & $\begin{array}{l}0 \\
\dot{\infty}\end{array}$ & $\hat{r}$ & $\underset{f}{\stackrel{f}{f}}$ & $\underset{\dot{\sigma}}{\stackrel{\alpha}{\sigma}}$ \\
\hline & & $=$ & in & $\begin{array}{l}\infty \\
i \\
i \\
\dot{q}\end{array}$ & $\stackrel{m}{m}$ & $\begin{array}{l}\infty \\
0 \\
0\end{array}$ & $\stackrel{\infty}{\circ}$ & 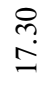 & $\underset{-}{F}$ & $\stackrel{\infty}{\circ}$ & $\begin{array}{l}m \\
\infty \\
\infty\end{array}$ & $\stackrel{?}{\circ}$ & 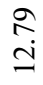 & $\underset{\infty}{\stackrel{1}{\circ}}$ \\
\hline $\begin{array}{l}\tilde{J} \\
\tilde{J} \\
j \\
0\end{array}$ & $\begin{array}{l}\tilde{n} \\
\tilde{\tilde{U}} \\
\tilde{\tilde{U}}\end{array}$ & 0 & 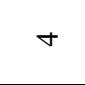 & $\overrightarrow{6}$ & $\stackrel{\infty}{a}$ & $\stackrel{+}{0}$ & $\ddot{0}$ & $\stackrel{\infty}{\circ}$ & $\stackrel{+}{+}$ & $\hat{\sigma}$ & 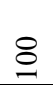 & in & $\stackrel{\hat{\infty}}{\rho}$ & $\stackrel{\infty}{\sim}$ \\
\hline & $\begin{array}{l}\overline{\tilde{U}} \\
\stackrel{\mathbb{G}}{*}\end{array}$ & & $n$ & $\begin{array}{l}\dot{0} \\
\dot{\sigma}\end{array}$ & $\vec{m}$ & $\hat{o}$ & $\overrightarrow{0}$ & $\stackrel{n}{\simeq}$ & $\stackrel{\Upsilon}{\sim}$ & $\overrightarrow{0}$ & $\begin{array}{l}\infty \\
\alpha\end{array}$ & $\tilde{o}$ & $\hat{\varrho}$ & $\begin{array}{l}n \\
\infty \\
\infty \\
\infty\end{array}$ \\
\hline & & t & $N$ & $\overline{6}$ & $\begin{array}{l}0 \\
\infty \\
\infty\end{array}$ & $\ddot{n}$ & $\stackrel{\circ}{\circ}$ & $\hat{o}$ & in & 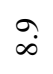 & $\begin{array}{l}\dot{\sigma} \\
\text { aे }\end{array}$ & : & $\hat{\vec{f}}$ & $\stackrel{?}{f}$ \\
\hline & & & - & 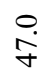 & $\stackrel{m}{m}$ & $\grave{0}$ & $\stackrel{\circ}{\circ}$ & $\ddot{n}$ & $\stackrel{\circ}{i}$ & $\overrightarrow{0}$ & $\begin{array}{l}0 \\
\dot{\alpha}\end{array}$ & 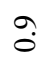 & $\begin{array}{l}\stackrel{0}{=} \\
=\end{array}$ & $\frac{n}{\infty}$ \\
\hline 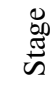 & $\begin{array}{l}\frac{y}{0} \\
\Omega\end{array}$ & 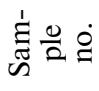 & $\begin{array}{l}\overrightarrow{\frac{\pi}{D}} \\
\bar{D} \\
\tilde{n}\end{array}$ & $\stackrel{N}{\circ}$ & 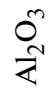 & $\begin{array}{l}0 \\
\Phi \\
\end{array}$ & $\sum_{\Sigma}^{\circ}$ & $\begin{array}{l}0 \\
\tilde{U}\end{array}$ & $\begin{array}{l}0 \\
\underset{Z}{N}\end{array}$ & $\underset{\sim}{0}$ & 完 & 5 & $\stackrel{2}{z}$ & $\frac{\xi}{<}$ \\
\hline
\end{tabular}


basalts (in contrast to mugearites) on the $\mathrm{TiO}_{2}-\mathrm{F} / \mathrm{FM}$ ratio are situated in the field of relatively low-Ti hawaiites that do not contain amphibole (Fig. 7f). Comparison of amphibole hawaiites and mugearites on the basis of the ratio of these elements is difficult because of sharp differences in the $\mathrm{TiO}_{2}$ content in the host rocks. Water-saturated anomalous mugearites also differ in having sharply higher anorthite molecules in plagioclase relative to the normative composition (Fig. 8c, sample 154).

5. The Trachybasalt-hawaiite-mugearite association of the late stage areal volcanism is observable sporadically (Fig. 2, field V). Some trachybasalts plot in the field of the same type of rocks in the intermediate association (field II) and are very similar to them both in composition and generation conditions. Several analyses are situated in the intermediate position between the fields II and IV. Hawaiites and mugearites completely occupy the field of rocks of the same name in the intraplate association (field IV) and also are very similar in many parameters to volcanic rocks of this type. In general, rocks of this association are characterized by the absence of amphibole and orthopyroxene and by control of the early aluminous spinel, which in the course of differentiation gives place to titanomagnetites. This attests to the relative dryness of the original melts and low oxygen fugacity.

Here, we may also distinguish two rock series with two differentiation trends that correlate according to the $\mathrm{Nb}-\mathrm{K}$ ratio (Fig. 2a), but are differently directed: (1) hawaiite-trachybasalt (Fig. 2b-d, hawaiites: samples 2627, k43; trachybasalts: samples 49060, 49061; basalt, sample k48) while increasing $\mathrm{Nb}$ and $\mathrm{SiO}_{2}$ of rocks, and (2) trachyandesite-basalt-mugearite (Fig. 2b-d, andesite-basalt 49055; mugearites: 163, $158,159,49051, \mathrm{k} 36-1,2602)$ as the content of $\mathrm{Nb}$ and $\mathrm{SiO}_{2}$ decreases and (2) the trachyandesitebasaltmugearite association (Fig. 2b-2c, andesite-basalt 49055; mugearites: 163, 158, 159, 49051, k36-1, 2602) as the contents of $\mathrm{Nb}$ and $\mathrm{SiO}_{2}$ increase.

The first trend is a decompressional one judging by the decreasing concentrations of $\mathrm{Nb}$ and $\mathrm{Ta}$ and the second is pseudo-fractional similar to that in association IV.

Moderate enrichment in manganese of olivines and low $\mathrm{MnO}$ contents in clinopyroxenes (Fig. 5g, 5h) are observed in most trachybasalts and all andesite-basalts of the first series. In this regard they are similar to trachybasalts of the early stage and hawaiites and andesitebasalts of the middle stage of areal volcanism, which were generated with low oxygen fugacity. Olivines from mugearites are more ferruginous and, in high $\mathrm{MnO}$ and low $\mathrm{CaO}$ (Figs. 5g and $10 \mathrm{~g}$ ), correspond to oxidizing conditions of formation, the same as for the mugearites of the middle stage. Anomalously high magnesian num- bers in clinopyroxenes of some mugearites and andesite-basalts of Mount Chernaya are also noted (Fig. 6, samples 159, 158, k51). For the former, the numbers significantly exceed those of the early olivines (in the same samples) and are higher than in clinopyroxenes from the mugearites of the middle stage.

Andesite-basalts of Mount Chernaya are characterized by higher basicity of the early plagioclase generations (Fig. 8d, sample k51), which is accompanied by low $\mathrm{CaO}$ contents in coexisting clinopyroxenes (Fig. 10h). The $\mathrm{TiO}_{2}-\mathrm{SiO}_{2}$ ratio (Fig. 2c) shows that with a somewhat higher Ti content (corresponding to high $\mathrm{Nb}$ contents), the andesite-basalts of Mount Chernaya (samples 2607, 2608, 2609) and "anomalous" mugearites (samples 158, 159) are significantly enriched in silica, and mugearites are also rich in alkalies (Fig. 2d), which "throws" them away from the line of the differentiation trend of the respective rock groups. This circumstance, along with abundant gabbroid xenolith material that occurs in the Chernaya rocks, is good evidence of the large role of hybrid rock varieties during this stage, which was already mentioned in the first part of the paper [Koloskov et al., 2011].

\section{Hypothetical Petrologic Model for the Generation of the Kekuknai massif and Magma Petrogenesis}

In the course of Kekuknai massif evolution islandarc volcanism gave way to intraplate volcanism. These two types of volcanism are usually considered as being opposed to each other because they are supposed to have different sources and mechanisms of formation. The first type is associated with subduction processes [Volynets et al., 2010] and the second one, directly or indirectly, with the evolution of mantle plumes [Volynets, 1994]. None the less there are papers that underline the genetic affinity of these formations [Koloskov et al., 2001; Koloskov, 2006].

According to results of our studies, the most substantial differences in the character of discrete (in time) stages of volcanic activity, as well as in the petrology and geochemistry of its products are observed for rocks of the pre-caldera shield-shaped volcano on one side and post-caldera areal events on the other side. On the whole, on the background of wide compositional variations of the massif, one observes a persistent linear character of correlative trends of major, trace, and rare-earth elements in the trachybasalt-trachydacite and hawaiite-mugearite associations. We believe that the major role in the formation of the Kekuknai massif was played by magmas of trachybasalt and hawaiite types with characteristic features of island-arc and intraplate geochemical types; these magmas were supplied from (intermediate) magma chambers at different depths that directly feed the central-type volcano and the areal zone. The interaction of these melts is not excluded. 
However, the similarity of the isotopic characteristics of different rocks types from the massif [Koloskov et al., 2011] attests to a common mantle source and suggests considering them in a common fluid-magmatic system. Indeed, an analysis of staging and compositions of individual fragments (associations) of the Kekuknai massif (Fig. 2) demonstrates that they complement each other well, such that end members of one series continue in the initial compositions of another series.

On the whole, a petrologic model of the massif formation may be represented as a system of trends (Fig. 11). The decompressional hawaiite-andesitebasalt trend of the middle stage of areal volcanism (association IV) continues into the field of andesitebasalt cinder cones (Fig. 11, I), which differ only in the higher water saturation and oxidation degree of the relevant melts. On the other hand, the same trend, or rather its hawaiite component, may also be extended toward the trachybasalts of the early stage of areal volcanism (Fig. 11,2) because some hawaiites (by the $\mathrm{TiO}_{2}-$ $\mathrm{SiO}_{2}$ ratio) already deviate in that direction (Fig. 2c) and less differentiated varieties of these rocks are intermediate between trachybasalts and hawaiites. As well, crystallization of these "extreme" trachybasalts (the upper part of trend 2) began during control of $\mathrm{Cr}-\mathrm{Al}$ spinel $\left(\mathrm{Al}_{2} \mathrm{O}_{3}=27-29 \%\right)$ and only in the case of the most fluid-saturated trachybasalts of the neck (lower part of trend 2) (sample k53) does the crystallization take place in conditions of magnetite control. Similar directivity is observed in the hawaiite-trachybasalt trend of the late stage of areal volcanism (Fig. 11, trend 3]. Therefore, the areal volcanic rocks have a common decompressional trend, which in its initial part is consistent with hawaiites and then branches off toward water-saturated andesite-basalts (Fig. 11, trend 1]) on one side, or toward trachybasalts that are undersaturated with respect to the fluid phase and especially the aqueous phase (Fig. 11, trends $2-3$ ) on the other side. A common pattern exists: gradual transition from deeper intraplate rock types to shallower islandarc ones is accompanied by successively decreasing concentrations of indicator high-field strength elements ( $\mathrm{Nb}, \mathrm{Ta}, \mathrm{Zr}$, and $\mathrm{Hf}), \mathrm{La} / \mathrm{Yb}$ ratio, total alkalinity (see Fig. 11d) [Koloskov et al., 2011] and increasing oxygen fugacity and deoxidation of melts when this is connected with greater water saturation of the system or increasing basicity, when the evolution occurs under conditions of low fluid- and water-saturation. A successive change of paragenesis of sub-liquidus crystallization is observed: $\mathrm{AlSp}+\mathrm{Ol} \rightarrow \mathrm{CrAlSp} \pm \mathrm{Ol} \pm \mathrm{cPx} \pm$ $\mathrm{oPx} \rightarrow \mathrm{Hb}+\mathrm{mt} \pm \mathrm{Ol} \pm \mathrm{cPx} \pm \mathrm{oPx}+\mathrm{Pl}$, либо CrAlSp \pm $\mathrm{Ol}+\mathrm{cPx}+\mathrm{Pl} \pm$ mtt.

During the evolution of the fluid-magmatic system under discussion, in addition to decompression trends a number of other trends of fractional directivity exist (Figs. 11a-11c). They have a common characteristic feature: as $\mathrm{SiO}_{2}$ content and alkalinity grow, the concentration of high-field strength ( $\mathrm{Nb}, \mathrm{Ta}, \mathrm{Zr}$, and $\mathrm{Hf}$ ) and some fluid-mobile elements $(\mathrm{Rb}, \mathrm{Ba}, \mathrm{Th}, \mathrm{U}, \mathrm{Pb})$ increase, the $\mathrm{La} / \mathrm{Yb}$ ratio rises, and the $\mathrm{TiO}_{2}$ content decreases somewhat. It is significant that titanium behaves in the opposite way compared to other highfield strength elements. The mineralogical composition of the rocks that form these trends indicates that they were formed under conditions of high water saturation of the system and high oxygen fugacity. These are regular "island-arc" trends that might be interpreted as a result of crystallization differentiation and fractionation in the crystal-melt system. However, these real trends of compositional evolution (Figs. 11a-11c) are greatly different from those "virtual" trends, which form residual glass and glasses enclosed in minerals (Figs. 11d and $5 a-5 e)$. According to the data of [Naumov et al., 1997] in the general case (crystallization differentiation and fractionation) correspondence between whole-rock compositions and the composition of homogenized melt inclusions should be observed. We do not find such correspondences here. The "virtual" trends are much more alkaline, this is observed, for example, in comparing trends $4 \mathrm{c}$ and $5 \mathrm{a}$ for rocks and glasses of the precaldera edifice (Fig. 11d). However, it must be admitted that a few points of glasses from trachybasalts of the precaldera edifice do occur in the field of whole-rock compositions. Fractionation here was probably not completed and a succession of change of actually observed compositions resulted from the evolution of the fluidmagmatic system, which was just complemented by fractional differentiation. As well, "virtual" trends in minerals from hawaiites, mugearites and andesitebasalts (Figs. 11d, 5d, 5b, and 5c) are noted for high alkalinity, although a similar trend in minerals from one of andesite-basalt (sample 157) is, in contrast, depleted in alkalies (Figs, 11d, 5e). It is worth noting that the whole-rock composition of these rocks is also of low alkalinity, but complete correspondence between real and "virtual" trends is also not observed. Therefore, the compositions of the Kekuknai massif show divergence of trends, which indicates emanation rather than crystallization differentiation. Interestingly, a similar case of trend divergence based on the example of extrusive dacites of Mendeleev Volcano (Kunashir Island) is explained exactly as a result of fluid-magmatic differentiation [Bindeman and Dubik, 1990]. Since in the course of decompression evolution most melt-mobile components are lost, but simultaneously accumulated in the fluid-saturated part of the system, the associated trends are called compensating trends.

Thus, here we have a stratified fluid-magmatic system with a large role of fluids in the upper part and more magmatogene in the lower part (both for the system as a whole and its separate fragments, which reflect the differentiation of the system in intermediate chambers). In 


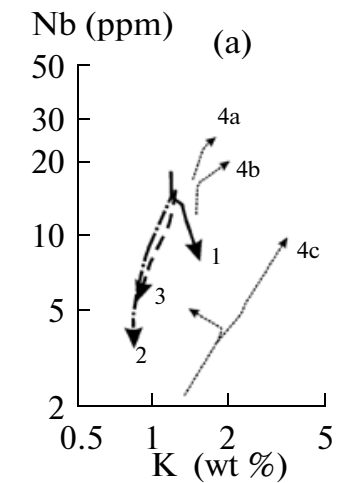

$\mathrm{Yb}_{\mathrm{n}}(\mathrm{ppm})$

7

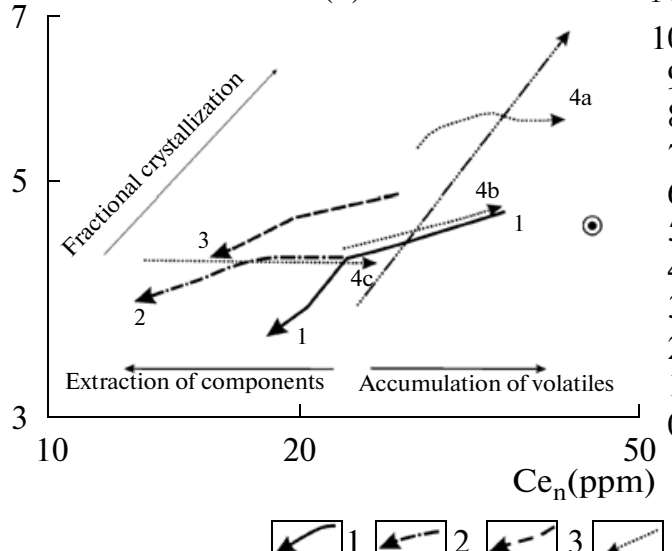

$\mathrm{TiO}_{2}($ wt \%)

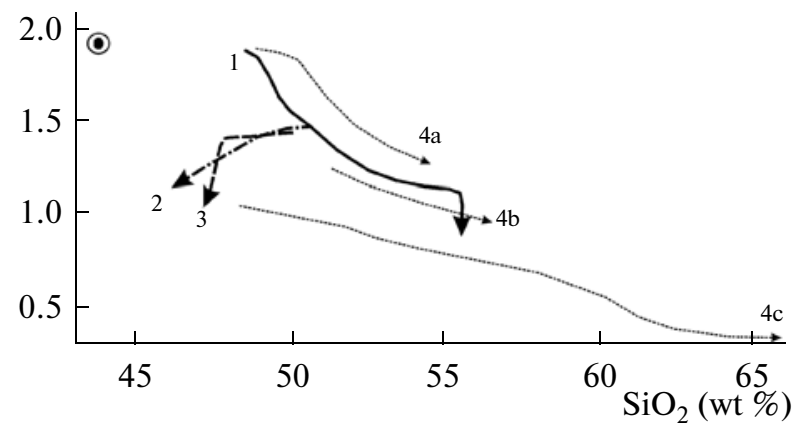

(d)

(c)

$$
\mathrm{Na}_{2} \mathrm{O}+\mathrm{K}_{2} \mathrm{O}(\text { wt \%) }
$$

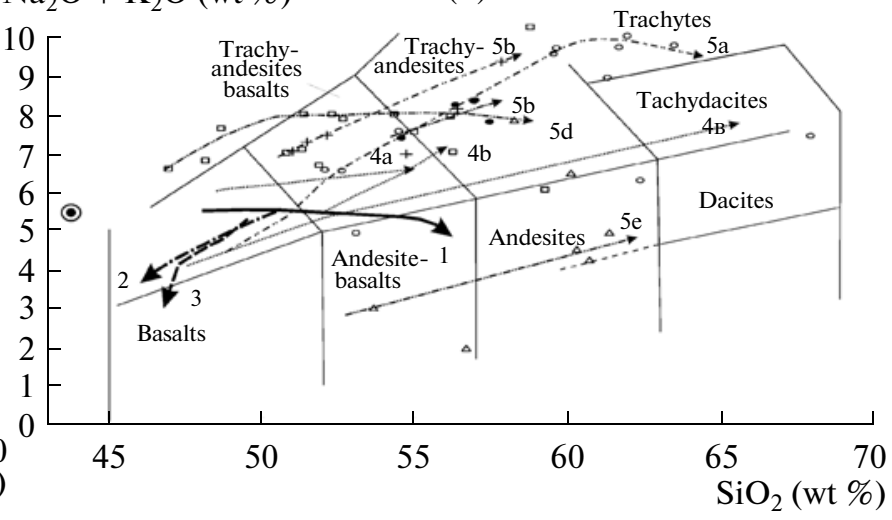

Fig. 11. Supposed trends of evolution of melts compositions for different stages of Kekuknai massif evolution in coordinates: $\mathrm{Nb}$ $\mathrm{K}(\mathrm{a}), \mathrm{Yb}_{\mathrm{n}}-\mathrm{Ce}_{\mathrm{n}}$ (b), $\mathrm{TiO}_{2}-\mathrm{SiO}_{2}$ (c) and $\mathrm{Na}_{2} \mathrm{O}+\mathrm{K}_{2} \mathrm{O}-\mathrm{SiO}_{2}$ (d). (1-7) trend types: (1-3) decompressional: (1) hawaiites-andesite-basalts of the intermediate stage of areal volcanism and amphibole andesite-basalts of cinder cones, (2-3): hawaiites-trachybasalts of intermediate-early (2) and late (3) stages of areal volcanism, (4) compensating hawaiites-mugearites: intermediate (4a) and late (4b) stages of areal volcanism and trachybasalts-trachyandesite-basalts of pre-caldera stage and extrusions (4c), (5) melt inclusions in minerals and residual glasses from the following rocks: trachybasalts-trachyandesite-basalts, dacites, of pre-caldera state and extrusions (5a), amphibole andesite-basalts of cinder cones (5b, 5e), mugearites of the late stage of areal volcanism (5c), hawaiites of intermediate stage (5d); (6) trend of melts evolution of Belogolovskii volcano, (7) evolution of melts during fractional crystallization, extraction of components and accumulation of volatiles; (8) supposed composition of primary melts; (9-13) compositions of melt inclusions in minerals and residual glasses from the following rocks: trachybasalt-trachydacite association (9), hawaiites of intermediate stage (10), andesite-basalts of cinder cones (11), mugearites of the late stage (12), andesite-basalts of intermediate stage of areal volcanism (13).

$\mathrm{Yb}_{\mathrm{n}}, \mathrm{Ce}_{\mathrm{n}}$ are values of the respective components when normalized by their concentrations in pyrolite (primitive mantle) after [Sun and McDonougt, 1989].

that case the model of the formation of the Kekuknai massif may be imagined as a conveyer ("escalator") that successively supplies the material of this system to the surface. The "operation" of this "escalator" was possibly suspended twice in intermediate chambers, when daughter magmas of hawaiite or trachybasalt composition separated. The relative "dehydration" of the system at the beginning of the areal volcanism stage (trachybasalt association) was most probably connected to extraction of fluid-mobile components during caldera formation, as was shown in the first part of this paper [Koloskov et al., 2011]. This situation possibly repeated itself in the late stage of the system's evolution (the formation of a mini-caldera in the NE part of the region, which was already mentioned in the first part of the paper). The role of pressure (a difference in magma chambers depths) as the leading factor that determines the difference in the compositions of ascending magmas has been repeatedly underlined both in the Russian [Koloskov, 2006] and in the foreign [Whitaker et al., 2006] literature.

Some mineralogical features (the presence of various microinclusions, such as olivine microdolerites, olivine pyroxenites, xenocrysts of quartz in pyroxene rims, acid plagioclase with inversion zones overfilled with apo-glass microinclusions) in andesite-basalts of cinder cones and more crystallized dykes and necks suggest possible hybridism or contamination of source rocks with crustal material. Now, we will try to estimate the possible effects of these processes on the total balance of the compositions of the Kekuknai massif. Some 
andesite-basalts and mugearites of the late stage of areal volcanism bear these features of crustal contamination, but they have anomalous compositions. In general, the rocks of the areal volcanism are characterized by subaphyric, in effect "chilling," textures indicating their rapid crystallization. The appearance of crystallized marginal zones in intermediate chambers obviously might be a serious obstacle for the formation of large volumes of hybrid rocks. Therefore, the recorded features of hybridism that are not accompanied by substantial changes in rock compositions can only have exclusively petrologic interest.

The model of a petrologic "escalator" supposes the existence of lower levels of the structure. It is therefore necessary to solve the problem of parent melt composition. Neither hawaiites nor trachybasalts of the Kekuknai massif are consistent with mantle melts, although they have mantle isotope characteristics [Koloskov et al., 2011]. They have no mantle xenoliths and they are characterized by moderate concentrations of such indicator elements as $\mathrm{Nb}, \mathrm{Ta}, \mathrm{Zr}$, and $\mathrm{Hf}$, which they could lose at the early stages of evolution. Earlier [Koloskov et al., 2001], based on studies of Kamchatka xenolith-bearing volcanic rocks of the intraplate type, we supposed that initial melts for them might have hightitanium magnesian basanitic compositions. A similar type of volcanic rocks with isotope characteristics close to those of the Kekuknai rocks but higher concentrations of high-field strength elements was described for western Kamchatka in the area of Mount Khukhch [Perepelov et al., 2007]. When plotted in diagrams (Fig. 11), the average compositions of these basanites are located at the beginning of decompression trends. Therefore, we may suppose that parent melts for rock associations of the massif under discussion were similar in their compositions to the basanites of Mount Khukhch.

\section{CONCLUSIONS}

1. The mineralogical composition of the rocks of the Kekuknai massif is considered in detail. The use of previously known and newly developed indicator properties of rock-forming minerals allowed the reconstruction of the general picture of magmatic melt evolution and the conditions of rock crystallization in the Kekuknai massif (various fluid and water saturation levels, as well as the oxidation state of the system).

2. Dominantly island-arc or dominantly intraplate characteristics in rocks compositions of the massif are found at different evolutionary stages of the integrated fluid-magmatic system. The parent basanitic magma evolved through the appearance of daughter trachybasalt magmas (the pre-caldera evolution stage) or hawaiite magmas (areal volcanism) in intermediate chambers.
3. The decompression evolution of these magmas and emanation-magmatic differentiation of melts together with crystallization differentiation resulted in the formation of all the diversity of the rocks of the Kekuknai massif.

4. The model of a fluid-magmatic "escalator" is suggested with three types of differentiation trends:

(1) The decompressional type, whose evolution proceeds along the line hawaiites-andesite-basalts with low water saturation and low oxygen fugacity at the beginning, but with an increase in these parameters when passing to the andesite-basalts of cinder cones; or in direction of areal trachybasalts under conditions of the secondary "dehydration" of melts during the extraction of the fluid phase during caldera development;

(2) The compensating type, which appears parallel to the first one under conditions of high water saturation in the system and proceeds in the direction hawaiitesmugearites or trachybasalts-trachydacites and reflects the results of component redistribution during the emanation or emanation-crystallization differentiation of melts;

(3) "Virtual" trends formed by melt inclusions or residual glasses, which play an important role because they reveal the actual picture of the relationship of emanation and crystallization differentiation in the course of the development of the volcanic massif.

\section{ACKNOWLEDGMENTS}

We are grateful to V.V. Anan'ev for carrying out several microprobe analyses and also to L.I. Bazanova and O.V. Dirksen for providing additional materials on rock compositions.

\section{REFERENCES}

Bindeman, I.N. and Dubik, F.Yu., High-silica residual melt as a result of differentiation: Extrusive dacites of Mendeleev Volcano, Dokl. AN, 1990, vol. 312, no. 3, pp. 702-706.

Feeley, T.C. and Dungan, M.A., Compositional and dynamic controls on mafic-silicic magma interactions at continental arc volcanoes: Evidence from Cordon El Guadal, Tatara-San Pedro, J. Petrol., 1996, vol. 37, no. 6, pp. 1547-1577.

Grib, E.N., Pyroxenes in the effusive-explosive complex of the Uzon-Geiser-Valley depression, eastern Kamchatka, Vulkanol. Seismol., 1997, no. 4, pp. 14-35.

Koloskov, A.V., Anomalous magmatic zones at present-day island arc systems: The Koryak-Kamchatka volcanic zone, in Geodinamika, magmatizm i metallogeniya Vostoka Rossii (Geodynamics, Magmatism, and Metallogeny in Eastern Russia), Book 1, Khanchuk, A.I., Ed., Vladivostok: Dal'nauka, 2006, pp. 398-417.

Koloskov, A.V., Puzankov, M.Yu., and Pirozhkova, E.S., Ultramafic Inclusions in Island Arc Basaltoids: The Problem of the Composition and Genesis of the Transitional "CrustMantle Mixture" Layer in Island Arc Systems, in Geodinamika $i$ vulkanizm Kurilo-Kamchatskoi ostrovoduzhnoi 
sistemy (The Geodynamics and Volcanism of the KurilKamchatka Island Arc System), Petropavlovsk-Kamchatskii: IVGiG DVO RAN, 2001, pp. 123-152.

Koloskov, A.V., Flerov, G.B., Perepelov, A.B., Melekestsev, I.V., Puzankov, M.Yu., and Filosofova, T.M., Evolution stages and petrology of the Kekuknai volcanic massif as reflecting the magmatism in backarc zone of Kuril-Kamchatka island arc system. Part 1. Geological position and geochemistry of volcanic rocks, J. Volcanol. Seismol., 2011, vol. 5, no. 5, pp. 312-334.

Martynov, Yu.A. and Chubarov, V.M., Pyroxenes as indicators for the genesis of the Eocene/Miocene contrasting volcanogenic formation in the lower Amur R. valley, Vulkanol. Seismol., 1982, no. 5, pp. 23-34.

Naumov, V.B., Kovalenko, V.I., Babanskii, A.D., et al., Genesis of andesites as revealed by studies of melt inclusions in minerals, Petrologiya, 1997, vol. 5, no. 6, pp. 654-665.

Panjasawatwong, Y., Danyushevsky, L.V., Crawford, A., et al., An experimental study of the effect of melt composition on plagioclase-melt equilibrium at 5 and $10 \mathrm{kbar}$ : Implications for origin of magmatic high-An plagioclase, Contrib. Mineral. Petrol., 1995, vol. 118, pp. 420-432.

Perepelov, A.B., Puzankov, M.Yu., Ivanov, A.V., et al., Neogene Basanites of Western Kamchatka: Mineralogic and Geochemical Features and the Geodynamic Setting, Petrologiya, 2007, vol. 15, no. 5, pp. 524-546.

Petrograficheskii kodeks (Petrographic Code) Bogatikov, O.A. et al., Eds., St. Petersburg, 2009, pp. 24-25.

Ringwood, A.E., Composition and Petrology of the Earth's Mantle, McGraw-Hill, 1975.

Speidel, D.H. and Nofriger, R.H., P-T-Fo2 relations in the system $\mathrm{Fe}-\mathrm{O}-\mathrm{MgO}-\mathrm{SiO}_{2}$, Am. J. Sci., 1968, vol. 266, no. 5, pp. 205-238.
Sun, S.S. and McDonough, W.F., Chemical and isotopic systematics of oceanic basalts: Implications for mantle composition and processes, in Magmatism in the Ocean Basins, Geol. Soc. Lond. Spec. Publ. Vol., Saunders, A.D. and Norry, M.J, Eds., 1989, vol. 42, pp. 313-345.

Volynets, O.N., Geochemical types, petrology, and genesis of Late Cenozoic volcanic rocks from the Kurile-Kamchatka island-arc system, International Geology Review, 1994, vol. 36, pp. 373-405.

Volynets, O.N., Koloskov, A.V., Popolitov, E.I., et al., Geochemical features of olivines from different types of Quaternary basalts of Kamchatka and the Kuril Islands in connection with their petrogenesis, Geokhimiya, 1975, no. 3, pp. 412-419.

Volynets, O.N. and Koloskov, A.V., Plagioklazy chetvertichnykh effuzivov $i$ maloglubinnykh intruzivov Kamchatki (Plagioclases in Quaternary Effusive Rocks and Shallow Intrusive Bodies in Kamchatka), Novosibirsk: Nauka, 1976.

Volynets, A. and Churikova, T., Woerner, G., et al., Mafic Late Miocene-Quaternary volcanic rocks in the Kamchatka back arc region: Implications for subduction geometry and slab history at the Pacific-Aleutian junction, Contrib. Mineral. Petrol., 2010, vol. 159, no. 5, pp. 659-687.

Whitaker, M.L., Nekvasil, H., Lindsley, D.H., et al., The Role of Pressure in Producing Compositional Diversity in Intraplate Basaltic Magmas, J. Petrol., 2006, vol. 48, no. 2, pp. 366-393.

Zinov'ev, V.I., Determination of plagioclase composition from chemical analyses of igneous rocks, Geol. Geofiz., 1964, no. 12 , pp. $140-144$.

Translated by M. Isakin 